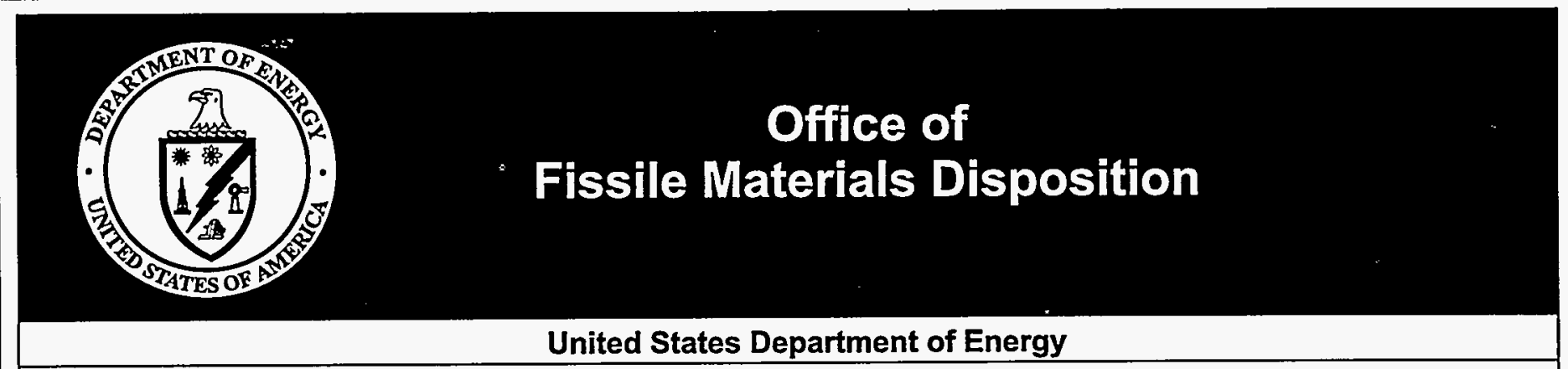

\title{
Pit Disassembly and Conversion Demonstration Environmental Assessment and Research and Development Activities
}

DISTRIBUTION OF THIS DOCUMENT IS UAHLMITEO

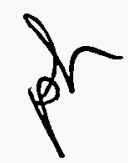

\author{
RECEIVED
}

SEP 141998

OSTI

\section{August 1998}




\section{DISCLAMMER}

This report was prepared as an account of work sponsored by an agency of the United States Government. Neither the United States Government nor any agency thereof, nor any of their employees, makes any warranty, express or implied, or assumes any legal liability or responsibility for the accuracy, completeness, or usefulness of any information, apparatus, product, or process disclosed, or represents that its use would not infringe privately owned rights. Reference herein to any specific commercial product, process, or service by trade name, trademark, manufacturer, or otherwise does not necessarily constitute or imply its endorsement, recommendation, or favoring by the United States Goyernment or any agency thereof. The views and opinions of authors expressed herein do not necessarily state or reflect those of the United States Government or any agency thereof. 


\section{DISCLAIMER}

Portions of this document may be illegible in electronic image products. Images are produced from the best available original document. 


\section{TABLE OF CONTENTS}

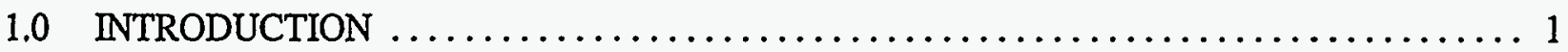

1.1 Related National Environmental Policy Act Reviews .................... 3

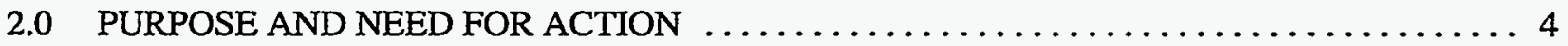

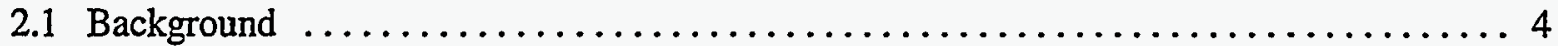

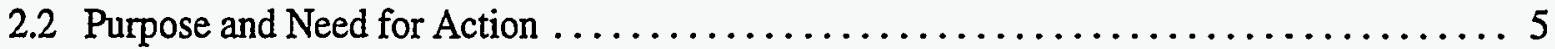

3.0 PROPOSED PIT DISASSEMBLY AND CONVERSION DEMONSTRATION $\ldots \ldots \ldots \ldots .6$

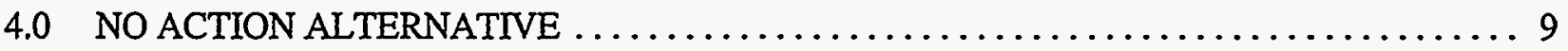

5.0 AFFECTED ENVIRONMENT $\ldots \ldots \ldots \ldots \ldots \ldots \ldots \ldots \ldots \ldots \ldots \ldots \ldots \ldots \ldots \ldots \ldots \ldots \ldots \ldots$

5.1 History and Current Mission of Los Alamos National Laboratory $\ldots \ldots \ldots \ldots \ldots \ldots \ldots$

5.2 Project Area, Facilities, and Infrastructure $\ldots \ldots \ldots \ldots \ldots \ldots \ldots \ldots \ldots \ldots \ldots \ldots \ldots \ldots \ldots \ldots \ldots$

5.3 Environmental Resources . . . . . . . . . . . . . . . . . . . . . . . . . . . . . 13

$5.3 .1 \quad$ Water Quality $\ldots \ldots \ldots \ldots \ldots \ldots \ldots \ldots \ldots \ldots \ldots \ldots \ldots \ldots \ldots \ldots \ldots \ldots \ldots \ldots \ldots, 13$

$5.3 .2 \quad$ Air Quality $\ldots \ldots \ldots \ldots \ldots \ldots \ldots \ldots \ldots \ldots \ldots \ldots \ldots \ldots \ldots \ldots \ldots \ldots \ldots \ldots, 14$

5.3.3 Radiation Exposure .................................. 14

5.3.3.1 Perimeter Monitoring $\ldots \ldots \ldots \ldots \ldots \ldots \ldots \ldots \ldots \ldots \ldots \ldots \ldots \ldots \ldots \ldots \ldots, 15$

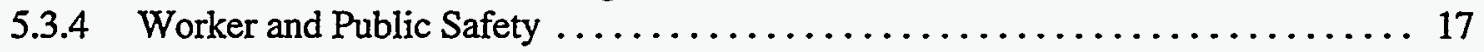

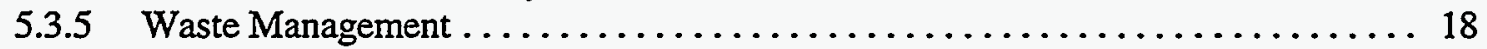

5.3.5.1 Transuranic Waste $\ldots \ldots \ldots \ldots \ldots \ldots \ldots \ldots \ldots \ldots \ldots \ldots \ldots \ldots \ldots \ldots \ldots, 18$

5.3.5.2 Low-Level Waste ............................... 18

5.3.5.3 Mixed Low-Level Waste $\ldots \ldots \ldots \ldots \ldots \ldots \ldots \ldots \ldots \ldots \ldots$

5.3.5.4 Hazardous Waste $. . \ldots \ldots \ldots \ldots \ldots \ldots \ldots \ldots \ldots \ldots \ldots \ldots, 18$

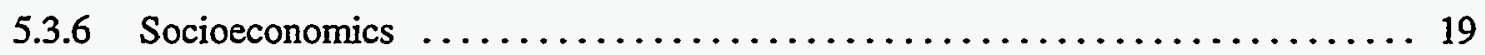

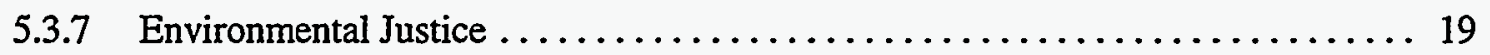

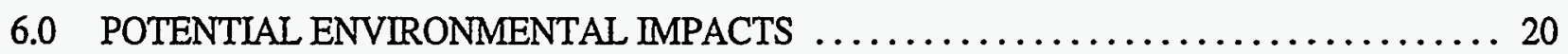

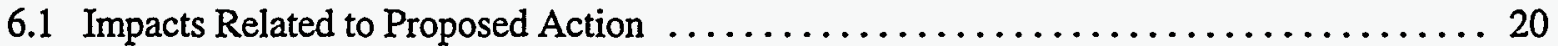

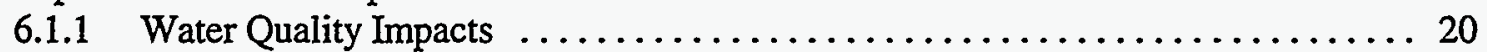

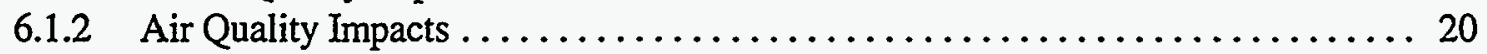

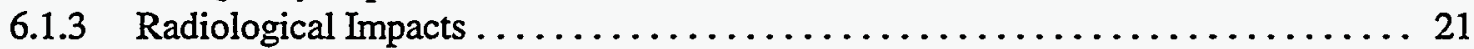

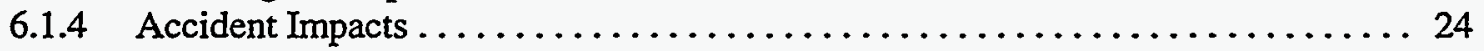

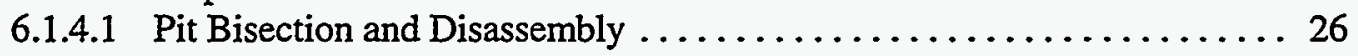

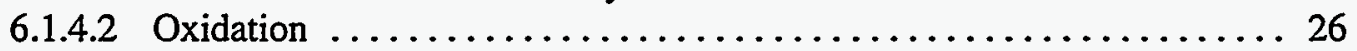

6.1.4.3 Gallium Removal ................................. 27

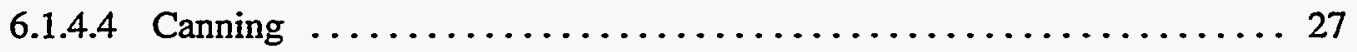

6.1.4.5 Electrolytic Decontamination .......................... 28

6.1.4.6 Nondestructive Assay ............................. 28

6.1.4.7 Preliminary Integrated Process Hazard Analysis .............. 29

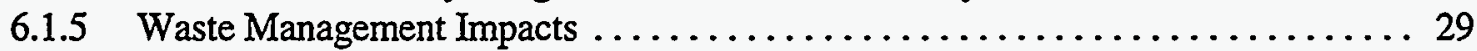

6.1.5.1 Transuranic Waste ............................... 29

6.1.5.2 Mixed Low-Level Waste .......................... 29

6.1.5.3 Low-Level Waste ............................... 29

6.1.5.4 Hazardous Waste $\ldots \ldots \ldots \ldots \ldots \ldots \ldots \ldots \ldots \ldots \ldots \ldots \ldots . \ldots \ldots$ 
The Final Environmental Impact Statement for the Continued Operation of the Pantex Plant and Associated Storage of Nuclear Weapon Components (DOE/EIS-0225, November 1996; ROD, January 27 1997), is a sitewide EIS that covers current and proposed facilities and activities at the DOE Pantex Plant in Amarillo, Texas, where plutonium pits are currently stored. The EIS analyzed the environmental impacts associated with continuing to conduct nuclear weapons operations at Pantex. Included in the EIS is an analysis of the effects of increasing the number of pits in interim storage from 12,000 to 20,000. In the ROD, DOE decided to implement the preferred alternative by: 1) continuing nuclear weapon operations involving assembly and disassembly of nuclear weapons at the Pantex Plant; 2) implementing facility projects, including upgrades and construction consistent with conducting these operations; and3) continuing to provide interim pit storage at the Pantex Plant and increasing the storage level from 12,000 to 20,000 pits.

The Environmental Assessment for the Proposed Interim Storage of Enriched Uranium Above the Maximum Historical Storage Level at the Y-12 Plant, Oak Ridge, Tennessee (DOE/EA-0929, September 1994; FONSI, September 1995) evaluated the continued receipt, prestorage processing, and interim storage of enriched uranium in quantities that would exceed the historic maximum storage level. The Y-12 PlantEA was issued in September 1994 and was followed by a FONSI in September 1995. DOE decided that the Y-12 Plant would store no more than 500 metric tons of HEU and no more than six metric tons of low-enriched uranium.

\subsection{PURPOSE AND NEED FOR ACTION}

\subsection{Background}

Since the early 1990s, the United States has been examining various ways to safely and securely disposition its surplus weapons-usable fissile materials. For the purposes of this EA, the term "disposition" relates to actions taken to meet nonproliferation goals by converting surplus plutonium to a form that meets the "Spent Fuel Standard." To support this effort, in December 1996, DOE published the Storage and Disposition Final PEIS which assessed the environmental impacts of various disposition alternatives for surplus weapons-usable plutonium.

In the Storage and Disposition Final PEIS ROD, DOE announced that it had decided to pursue a plutonium disposition strategy that allows for both immobilization of surplus weapons plutonium in glass or ceramic forms and the use of some of the surplus plutonium as MOX fuel in existing commercial reactors (DOE 1997c:1). The ROD also committed to a subsequent EIS, the SPD EIS, to evaluate the site-specific impacts associated with pursuing these disposition alternatives. Additionally, the ROD stated, "Based on appropriate NEPA review, DOE anticipates demonstrating the Advanced Recovery and Integrated Extraction System (ARIES) concept at LANL for pit disassembly/conversion ..." (DOE 1997c:20). Accordingly, this EA is being undertaken to determine whether there are any potentially significant environmental impacts associated with conducting, as an interim action before issuance of the SPD Final EIS ROD, the Pit Disassembly and Conversion Demonstration. ${ }^{2}$

1 The "Spent Fuel Standard" is defined by DOE as follows: The surplus weapon-usable plutonium should be made as inaccessible and unattractive for weapons use as the much larger and growing quantity of plutonium that exists in spent nuclear fuel from commercial power reactors (DOE 1996a: 1-5).

2 The purpose of this EA is also to discuss other ongoing, small-scale R\&D activities. As discussed in Section 7.0, these R\&D activities are needed to refine technical and feasibility information related to surplus plutonium immobilization, potential MOX fuel fabrication, and plutonium conversion. 


\subsection{Purpose and Need for Action}

The United States has declared 38.2 metric tons of weapons-usable plutonium surplus to national security needs. Additional quantities of plutonium may be declared surplus in the future; therefore, the Storage and Disposition Final PEIS analyzed (as does the SPD Draft EIS) the disposition of a nominal 50 metric tons of plutonium (DOE 1997c:2; DOE 1997a:7). Approximately 33 of the 50 metric tons of surplus plutonium are expected to come from clean metal including pits from dismantled nuclear weapons. The remainder would consist of plutonium in other forms (e.g., oxides and alloyed metal).

DOE is continuing to dismantle nuclear weapons (separating the plutonium pits from the rest of the weapons components), thereby increasing the inventory of surplus weapons pits. While these additional surplus pits are placed in safe, secure storage, the plutonium metal contained therein could readily be reused in nuclear weapons. Therefore, safe, secure storage alone would not meet the nonproliferation goals of the fissile materials disposition program.

Disposition of surplus plutonium metal, either through immobilization or through use as MOX fuel in commercial reactors, would require that it first be converted to an oxide form. Because the surplus plutonium would be subject to international safeguards, it must be unclassified. Therefore, for disposition, the surplus pits must be disassembled and converted to an unclassified oxide form.

DOE is currently dismantling a limited number of pits as part of weapons surveillance and rebuild efforts. However, the existing DOE infrastructure is only capable of dismantling a very limited number of pits and does not include the capability of converting the resulting plutonium metal to an unclassified oxide. Additionally, because of this limited throughput, the existing pit disassembly process has not been optimized and consists of a series of operations in a variety of separate (non-integrated) gloveboxes, which results in a burdensome, man-hour intensive operation and higher than desirable radiation exposure to involved workers.

DOE needs to develop the capability to disassemble surplus pits and convert the surplus plutonium metal to a suitable oxide form safely and efficiently. In order to develop this capability in a timely manner, safety and operational design information must be obtained from the actual disassembly of up to 250 representative pits and the conversion of the recovered plutonium to plutonium metal ingots and plutonium dioxide. A complicating factor is that there are many different types of pits of varying ages and therefore, the dose to which the workers would be exposed could vary considerably. In order to adequately protect workers in the potential pit disassembly and conversion facility, a wide range of spacing and shielding specifications needs to be developed, integrated, and tested. Concurrently, process parameters must be developed for the conversion of different pits to produce an unclassified oxide form that could be used in MOX fuel or immobilized.

The basic objectives of this demonstration are to:

- Demonstrate the feasibility of the pit disassembly and conversion process;

- Test various processes for the different parts of the pit disassembly and conversion process to optimize procedures and parameters and reduce dose to workers (as the number of pits to be dismantled would significantly increase);

- Develop processes, procedures and equipment for the disassembly of all types of surplus pits; and 
- Demonstrate that the plutonium metal from pits of varying types and ages can be consistently converted to an oxide form that is suitable for use as feed for MOX fuel and for immobilization.

The resulting experience would be used to supplement information developed to support the design of the full-scale disassembly and conversion facility should it be decided in the SPD EIS ROD to construct that facility.

\subsection{PROPOSED PIT DISASSEMBLY AND CONVERSION DEMONSTRATION}

In order to meet the purpose and need for the action described in Section 2.2, DOE proposes to test an integrated pit disassembly and conversion process on a relatively small sample of pits and non-pit, clean plutonium metal at LANL. The pits processed as a part of this demonstration would represent the diverse range of pits that DOE proposes to disassemble over the coming years.

The demonstration would be accomplished at LANL's Plutonium Facility-4 (PF-4) in TA-55, see Figure 3-1. No new facilities are needed to support this demonstration; however, minor internal modifications would be made to existing facilities. These minor modifications, relating to the installation of new gloveboxes, would not involve worker exposure.

Most work would be performed in a series of interconnected gloveboxes using remote handling, automation and computerized control systems, where possible, to minimize operator exposure, increase safety, and minimize the amount of waste generated by the process.

Implementation of this demonstration would require direct demonstration activities, such as pit bisection. Implementation would also require general support operations, such as packaging, receipt, and storage that are typical support activities at LANL and the originating sites, which have been analyzed in the Draft LANL Site-Wide EIS (DOE 1998a) and in other NEPA documentation. These direct and support activities include the following:

- $\quad$ shipment of pits and non-pit, clean plutonium metal from offsite to LANL;

- receipt, unpackaging, and placement into storage of offsite pit and non-pit, clean plutonium metal;

- interim storage of pit and non-pit, clean plutonium metal, awaiting use in the demonstration;

- $\quad$ removal of any external pit features;

- $\quad$ bisection and disassembly of pits;

- processing pit hemishells to separate the plutonium from other materials;

- recasting the plutonium to metal ingots or converting it to plutonium dioxide;

- thermally processing the plutonium to remove gallium and other impurities;

- $\quad$ sealing the plutonium in an appropriate container for storage;

- decontaminating the container; 


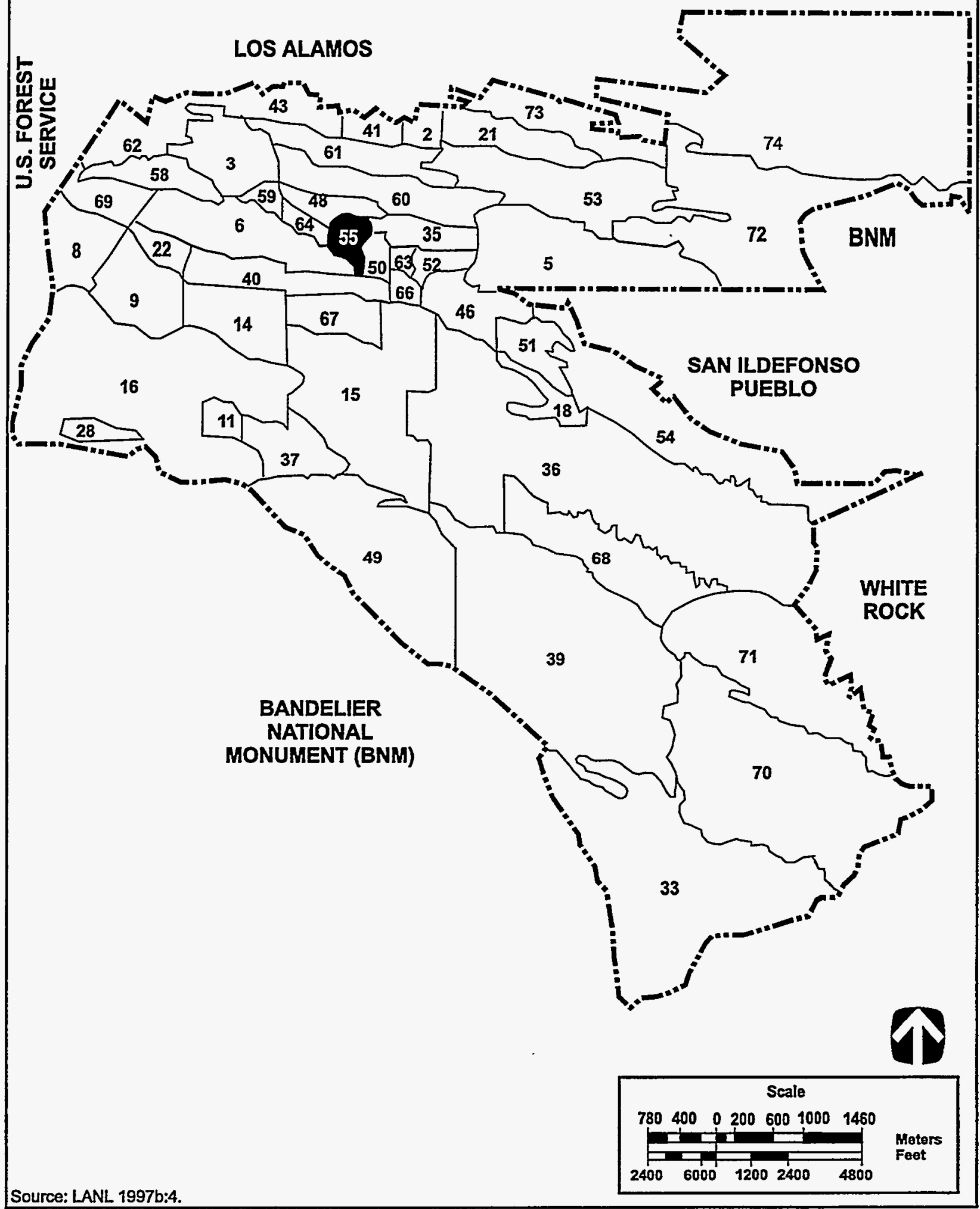

Figure 3-1. Technical Areas of Los Alamos National Laboratory 
- $\quad$ sealing the decontaminated container in a second container;

- performing nondestructive assay on all components for material accountability purposes; and

- $\quad$ storing the resulting plutonium metal and plutonium dioxide until an ultimate disposition decision is made.

All these direct and support activities are analyzed in this EA to capture the cumulative impact of this demonstration.

Some of the non-pit, clean plutonium metal to be processed in this demonstration would be derived from pit material separately processed through the Special Recovery Line (SRL) as part of Stockpile Stewardship activities to remove tritium contamination. This demonstration does not result in an increase in the number of pits processed through the SRL and therefore, does not increase total tritium releases or any other impacts associated with SRL operations. The impact of these SRL operations are included in the Draft LANL SiteWide EIS (DOE 1998a) and are also included in this EA to capture the total cumulative impact of the demonstration activities, support activities, and precursor activities at LANL (e.g., SRL).

TA-55 has historically performed plutonium processing activities similar to those required in this demonstration, and currently disassembles pits in a series of individual gloveboxes. Most of the plutonium, in the form of pits or metal, to be used in the demonstration would be taken from storage at LANL. Additional surplus pits may be shipped from the Pantex Plant near Amarillo, Texas or the Rocky Flats Environmental Technology Site (RFETS) near Golden, Colorado if there is a need to test additional types of pits. Additional plutonium in the form of metal would be shipped, if needed, from the Idaho National Engineering and Environmental Laboratory (INEEL) near Idaho Falls, Idaho; the Savannah River Site (SRS) near Aiken, South Carolina; or the Lawrence Livermore National Laboratory (LLNL) in Livermore, California.

The pits and non-pit, clean plutonium metal to be used in the demonstration would be staged in existing special nuclear material storage facilities at LANL. The plutonium metal and dioxide that would be produced during the demonstration would also be staged in existing special nuclear material storage facilities at LANL. No new storage construction would be required and there would be no need to increase the storage limits of the existing facilities. The demonstration would result in a small net increase ${ }^{3}$ in the amount of surplus plutonium at LANL. ${ }^{4}$ DOE intends to ship LANL's total surplus plutonium to the disposition site or sites that are chosen as a part of the ROD for the SPD Final EIS (DOE/EIS-0283), which was issued as a draft in July 1998. DOE expects to make that decision in early 1999. HEU would be recovered from some of the pits during the disassembly process ${ }^{5}$ and shipped to DOE's Oak Ridge Reservation (ORR) for storage

3 The net increase would be the result of pits and metal being shipped to LANL for use in the demonstration. Some of the existing surplus pits and metal at LANL would also be used in the demonstration. The amount of plutonium used in the demonstration would not cause an equal increase in the total surplus plutonium at LANL.

4 The Secretary of Energy's 1994 Openness Initiative stated that there was 1.5 metric tons of surplus weapons-usable plutonium at LANL.

5 The HEU recovery process would include electrolytic decontamination, which results in the buildup of solids that would be packaged as waste. The human health impacts of this recovery process are included in Section 6.1.3 and waste impacts in Section 6.1.5. 
in accordance with DOE's Y-12 Plant EA ${ }^{6}$ and the Storage and Disposition Final PEIS.

Currently, routine waste is produced at LANL in the following categories: transuranic waste (TRU), lowlevel waste (LLW), mixed low-level waste (MLLW), and hazardous waste. It is expected that small amounts of these types of waste would be produced by the proposed Pit Disassembly and Conversion Demonstration. In addition, small amounts of plutonium, americium and tritium may be released to the atmosphere.

\subsection{NO ACTION ALTERNATIVE}

Under the No Action Alternative, an integrated pit disassembly and conversion line would not be demonstrated at LANL. Research related to these activities would continue to be performed in a series of individual gloveboxes. Information that would be generated as a result of the proposed Pit Disassembly and Conversion Demonstration (e.g., specifications for the main operating line and information needed to optimize the layout in terms of shielding, residence time in the gloveboxes,-and distance between gloveboxes) would not be available under the No Action Alternative.

Other DOE sites were considered for this proposed demonstration. The only other site that was a potential alternative was LLNL because it is the only other DOE national laboratory with extensive, operating plutonium facilities that could be used to conduct the demonstration. LLNL-was-eliminated from further consideration because among other things, LLNL's plutonium administrative limits are significantly lower and would restrict the proposed demonstration. Furthermore, because much of the plutonium that would be used in the demonstration is already located at LANL, it would need to be transported to LLNL. In addition, the capabilities at LANL were readily available during the timeframe in which DOE needed the work to be conducted. Also, the majority of the gloveboxes that would be used in the demonstration are already at LANL. Consequently, there would be no need to decontaminate LANL gloveboxes for the express purpose of sending them to LLNL for use in the demonstration.

DOE has also considered other potential disassembly and conversion options as alternatives to the proposed demonstration. However, as explained below, none of the potential options are reasonable alternatives and, therefore, are not analyzed in detail in this EA. As one potential option, DOE has considered a demonstration that would involve disassembling a fewer number of pits. However, this option would not encompass all of the types of surplus pits that would be involved in surplus plutonium disposition (immobilization or MOX fuel) or continued safe storage. As such, this option would not meet the purpose and need for the proposed demonstration and would not generate complete information. For conversion, $\mathrm{DOE}$ has considered the potential alternative of converting only plutonium from pits, but not non-pit plutonium metal, to plutonium dioxide. Because this option would exclude plutonium metal, this option would not test and demonstrate conversion of all types of surplus plutonium material that may be subject to disposition under the MOX or immobilization approaches, would not generate complete information, and would not fully meet the purpose and need for the proposed demonstration. In addition, DOE has considered converting plutonium to a metal form only. This option would not test and demonstrate conversion of pit plutonium to the oxide form most suitable for either immobilization or MOX fuel. Thus, this option would not generate complete information, and would not fully meet the purpose and need for the proposed action.

6 The amount of HEU to be shipped to ORR for storage is within the bounding limit of 1.9 metric tons of HEU from LANL as set forth in the $\mathrm{Y}-12$ Plant EA (DOE 1994b:3-3). 


\subsection{AFFECTED ENVIRONMENT}

\subsection{History and Current Mission of Los Alamos National Laboratory}

In March 1943, a small group of scientists came to Los Alamos, New Mexico, located on a remote plateau high above the Rio Grande River for Project $Y$ of the Manhattan Project. Their goal was to develop the world's first nuclear weapon. By 1945, when the first nuclear device was tested at Trinity Site in southern New Mexico, more than 3,000 civilian and military personnel were working at Los Alamos Scientific Laboratory, which became LANL in 1981. LANL is owned by DOE and operated by the University of California under contract with DOE.

LANL's original mission to design, develop, and test nuclear weapons has broadened and evolved as technologies, United States priorities, and the world community have changed over time. It is now a multidisciplinary science and technology research facility. DOE programs supported by LANL include nuclear weapons stockpile stewardship and management; fissile materials disposition; environmental management; nonproliferation and international security, verification $R \& D$, nuclear safeguards and security, arms control and intelligence; energy research and energy technologies; and work for other government agencies such as the Department of Defense and the Nuclear Regulatory Commission (NRC) (DOE 1996a:3-304).

\subsection{Project Area, Facilities, and Infrastructure}

The Pit Disassembly and Conversion Demonstration line would be installed and operated within PF-4 in TA55 at LANL. The facilities at TA-55 are located on a 40-acre site about one mile southeast of LANL's core technical area, TA-3. TA-55 is situated adjacent to a LANL-owned and -controlled roadway, Pajarito Road, that is accessible to the public and passes along one side of and below TA-55.

Most of TA-55, including the main complex, is situated inside a restricted area surrounded by a double security fence and is considered a Category I safeguards and security facility. ${ }^{7}$ The TA-55 main complex has several major connected buildings: the Support Building; the Warehouse; the Plutonium Facility (PF-4), and the Calcium Building (see Figure 5-1). Various administrative, support, storage, security, and training structures are located throughout the main complex. The cornerstone R\&D facility at TA-55 is PF-4. Plutonium processing and research on plutonium metallurgy occurs in this facility, which is a two-story laboratory of approximately 151,000 square feet. Work in PF-4 includes:

- $\quad$ plutonium recovery (converting recovered material to plutonium metal);

- disassembly of weapons components;

- $\quad$ fabrication of ceramic-based reactor fuels (including MOX fuel); ${ }^{8}$

- $\quad$ processing plutonium-238 to produce heat sources for use in space, among other uses;

- development of materials control and accountability techniques;

- $\quad$ activities related to pit surveillance;

- plutonium component fabrication; and

- materials and properties R\&D.

7 Category I safeguards and security facilities are required to meet the highest security standards in the DOE complex. These facilities are used to house assembled weapons or pure products, such as pits and directly convertible plutonium materials in quantities of two kilograms or higher.

8 The fabrication of such MOX fuel is discussed in the Predecisional Draft Environmental Assessment for the Parallex Project Fuel Manufacture and Shipment and the Draft Site-wide Environmental Impact Statement on the Continued Operation of the Los Alamos National Laboratory. 


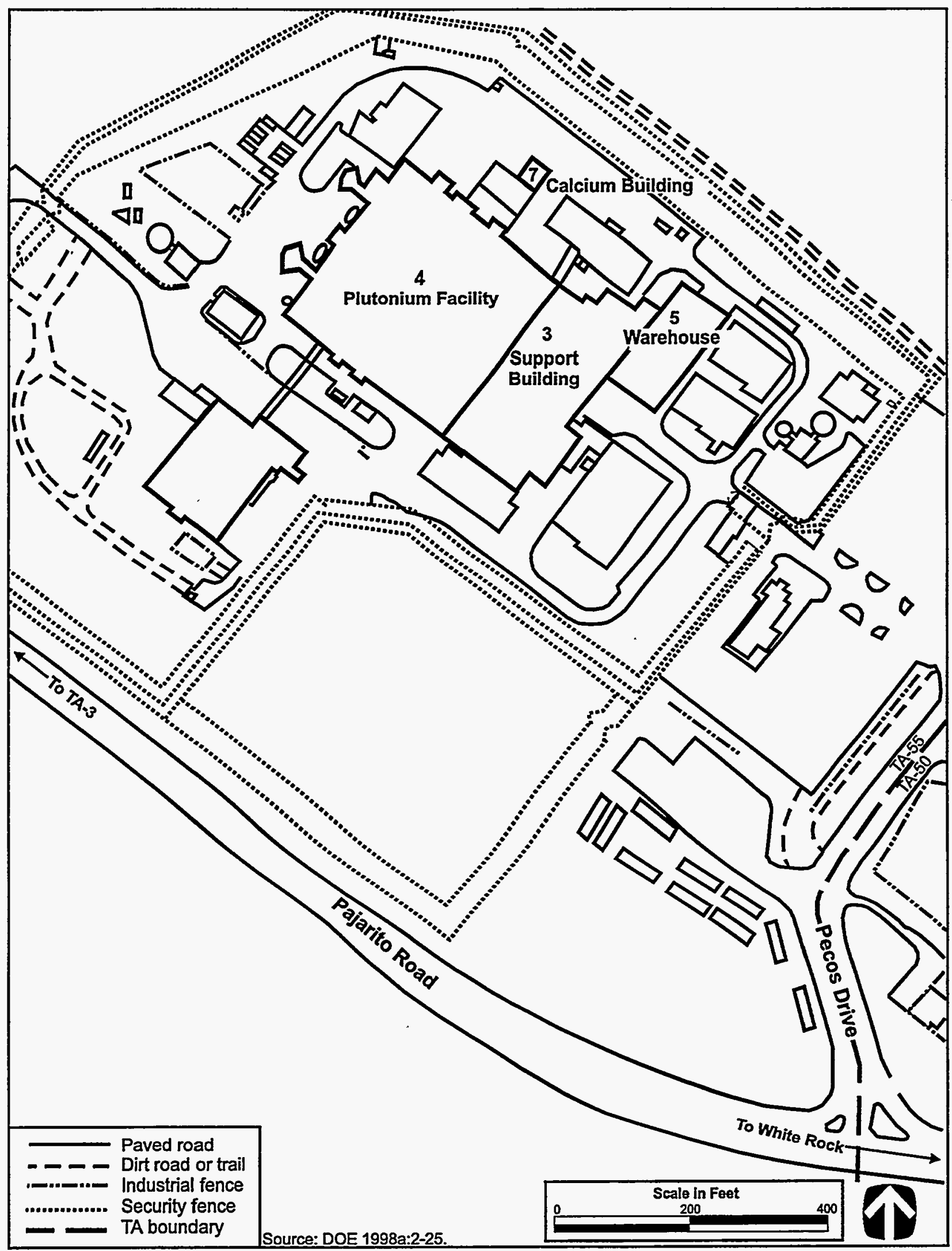

Figure 5-1. Technical Area-55 Facilities at Los Alamos National Laboratory 
$\mathrm{PF}-4$ is a reinforced concrete structure that complies with all required seismic standards. The overall design concept for PF-4 separates the building in halves, each of which contains its own ventilation systems and electrical substations. Half of the building is comprised of Areas 100 and 200 that contain the plutonium research and development laboratories, plutonium-238 operations, and the personnel decontamination area. Areas 300 and 400 constitute the remainder of the building and contain plutonium recovery, metal preparation and fabrication, and nondestructive assay laboratories. Large central corridors span the length of the four main areas of PF-4. Each of the processing areas is divided into rooms that contain gloveboxes for working with plutonium. The ventilation systems supporting the gloveboxes and all other buildingrelated utilities are located in the basement of the facility, which also contains the packing/unpacking room, the waste-handling areas, and the plutonium storage vault. This arrangement provides flexibility in meeting the ever changing needs of a R\&D facility (LANL 1996b:1).

The Pit Disassembly and Conversion Demonstration requires minor modifications to PF-4, relating to the installation of new gloveboxes, which would not involve worker exposure. The demonstration would utilize approximately 1,500 square feet of PF-4. Existing facility infrastructure at PF-4 would be used, including: utilities, environmental systems, systems for incoming pit assay, vault storage, special pit handling, and materials control and accountability. Analytical laboratory work on small samples (10 grams or less) from the demonstration would be conducted in the Chemical and Metallurgy Research (CMR) facility at LANL. It is expected that a total of 2,000 samples would be analyzed in TA-55 and CMR during the demonstration.

Infrastructure and supporting systems at TA-55 are required for the operating reliability, safety, and environmental integrity of PF-4. The supporting systems for PF-4 include:

- a confinement system that consists of three layers to prevent accidental releases of nuclear materials; these layers are gloveboxes, laboratory rooms, and the building ( $\mathrm{PF}-4$ );

- a ventilation system with appropriate high-efficiency particulate air (HEPA) filtering that contains four zones, all of which are maintained at a lower pressure than outside air to ensure that leaks are contained within the building and not released to the atmosphere;

- a conveyor system that transports contaminated materials and equipment to almost any point on the first floor, thereby limiting worker contact and exposures;

- a criticality detection system that monitors operations on the main processing floor of the plutonium facility, as well as in the basement vault, to detect gamma energy released from any fission of special nuclear material and to alert personnel to immediately evacuate $\mathrm{PF}-4$;

- a continuous air monitoring system that samples and analyzes air from multiple points throughout PF-4 laboratory areas, basement, ductwork, and exhaust stacks to ensure that personnel are warned of the release of radioactive material; and

- a radioactive liquid waste piping system that allows liquid low-level radioactive waste to be shipped directly to LANL's treatment facility at TA-50. 
Additional supporting systems for the entire TA-55 site, including PF-4, that enhance the overall safety of PF-4 include:

- two water storage tanks with capacities of 100,000 and 500,000 gallons;

- a fire detection system consisting of smoke detectors, thermal detectors, manual pull stations, and drop-box alarm stations;

- a fire suppression system consisting of a wet-pipe, automatic sprinkler protection system fed by two 150,000 gallon tanks;

- chilled-water systems for air tempering, heat absorption, and glovebox cooling;

- a glovebox vacuum system consisting of wet vacuum, dry vacuum; and ultrahigh vacuum;

- $\quad$ separate acid, caustic, industrial, and sanitary waste lines connected directly to LANL's waste treatment facilities; and

- $\quad$ process gas control systems (i.e., argon, helium, oxygen, nitrogen, hydrogen) (LANL 1996b:23).

\subsection{Environmental Resources}

The proposed Pit Disassembly and Conversion Demonstration would be located within an existing building, PF-4. Therefore, there would not be any new construction that could affect floodplains, wetlands, biological resources, or cultural resources. The following descriptions are focused on providing sufficient information on the resources that could be affected during operation of the demonstration or in the event of an accident. LANL is not listed on the U.S. Environmental Protection Agency's (EPA) National Priorities List (LANL 1997b:22).

\subsubsection{Water Quality}

LANL is required to meet effluent limitations under the National Pollutant Discharge Elimination System (NPDES) permit program. These permits establish specific chemical, physical, and biological criteria that an effluent must meet before it can be discharged. Overall compliance for the sanitary and industrial waste discharges during 1996 was 98.8 percent and 97.9 percent respectively. Based on a performance audit inspection conducted by EPA on September 16-17, 1996, the overall NPDES compliance program was rated superior (LANL 1997b:26, 30-31).

In 1996, LANL had 15 NPDES permits: one covering the effluent discharges at LANL, one covering the Hot Dry Rock Geothermal Facility (located 30 miles west of Los Alamos), and 13 covering storm water discharges. In January 1996, LANL's NPDES outfall permit included two sanitary wastewater treatment facilities and 95 industrial outfalls. By the end of 1996, LANL had eliminated nine permitted industrial outfalls in the NPDES permit. The University of California and DOE are co-permittees of the NPDES permits for LANL operations (LANL 1997b:26).

The Utility Building is the only permitted industrial outfall in TA-55. Liquid waste from TA-55 processing buildings is transferred to TA-50 where it is treated. Building 1, the Radioactive Liquid Waste Treatment Facility, in TA-50 also has a permitted industrial outfall. Both the TA-50 and TA-55 outfalls discharge into the Mortandad Canyon (DOE 1998a:4-54). 
Under LANL's existing NPDES permits, samples are collected for analysis on a weekly basis and reported to EPA and the New Mexico Environment Department, as required. During 1996, effluent limits were exceeded two times in 165 samples collected from the sanitary wastewater facilities. Effluent limits were exceeded 32 times in the 1,559 samples collected from the industrial outfalls. There were no exceedances for the TA-55 outfall. For the TA-50 outfall, on two occasions the daily chemical oxygen demand concentrations exceeded the permit limit. A chemical oxygen demand sampling program was implemented for this outfall (LANL 1997b:27).

\subsubsection{Air Quality}

Baseline concentrations at LANL for hazardous and toxic air pollutants are in compliance with concentration limits and guidelines approved by the New Mexico Environmental Improvement Board. Nonradiological criteria pollutants were monitored for several years at LANL without any detectable increases above typical regional background levels, so ambient monitoring was discontinued (LANL 1996a:95). Over 90 percent of all LANL's nonradiological air pollutant emissions are associated with industrial sources, such as power plants and the asphalt plant (LANL 1997b:69). These plants would continue to operate whether or not the Pit Disassembly and Conversion Demonstration is conducted at LANL, and therefore, are not evaluated as part of this EA. EPA limits the effective dose equivalent to any member of the public from radioactive airborne releases from DOE facilities to 10 millirem (mrem) per year. In 1996, the effective dose equivalent from LANL operations to the maximally exposed members of the public was estimated to be 1.93 mrem (LANL 1997b:23).

In 1991 and 1992, LANL received two Notices of Noncompliance from EPA for not meeting all provisions of the Code of Federal Regulations (CFR) "National Emission Standards for Emissions of Radionuclides Other Than Radon from Department of Energy Facilities" (EPA 1997). Specific findings included deficiencies in LANL's identification and evaluation of release sources, noncompliant stack monitoring equipment on all point release sources, using a shielding factor without previous EPA approval, and exceeding the 10 mrem per year standard. DOE negotiated a National Emission Standards for Hazardous Air Pollutants (NESHAP) Federal Facility Compliance Agreement (FFCA) with EPA Region 6, which was signed in June 1996. LANL is meeting the terms of this FFCA and achieved full compliance in June 1996 with the radionuclide NESHAP, as defined in the FFCA (LANL 1997b:42).

\subsubsection{Radiation Exposure}

LANL has an extensive air monitoring program in place on the site and in regional locations surrounding the site to detect radiological air releases. Because some of LANL's research involves radioactive materials that may enter the atmosphere through a stack, many of the stacks on the site are continually monitored in accordance with 40 CFR 61, Subpart H-National Emission Standards for Emissions of Radionuclides Other Than Radon from Department of Energy Facilities (EPA, 1997).

Due to ongoing work at LANL, very small amounts of radioactive elements, such as plutonium $(\mathrm{Pu})$, tritium, americium (Am), and uranium (U), are released to the atmosphere. As shown in Table 5-1, LANL's emission of these radioactive isotopes, as measured on a regional basis, is significantly lower than EPA Public Dose Limits. 
Table 5-1. Mean Annual Concentrations of Radioactivity Measured by LANL

\begin{tabular}{llcccc}
\hline Elements & Units & $\begin{array}{c}\text { Annual Regional } \\
\text { Mean }^{\mathrm{a}}\end{array}$ & $\begin{array}{c}\text { Highest for Any } \\
\text { Monitoring } \\
\text { Location }^{\mathrm{a}}\end{array}$ & $\begin{array}{c}\text { Highest Mean } \\
\text { EPA Public } \\
\text { Dose Limit }^{\mathrm{b}}\end{array}$ & $\begin{array}{c}\text { as a } \\
\text { Percentage of } \\
\text { EPA Limit }\end{array}$ \\
\hline${ }^{238} \mathrm{Pu}$ & $\mathrm{aCi} / \mathrm{m}^{3}$ & 0.1 & 19.8 & 2,100 & 0.9 \\
${ }^{239} \mathrm{Pu}$ & $\mathrm{aCi} / \mathrm{m}^{3}$ & 0.7 & 706.6 & 2,000 & 35.3 \\
${ }_{\mathrm{Tritium}}$ & $\mathrm{pCi} / \mathrm{m}^{3}$ & 0.3 & 400.3 & 1,500 & 26.7 \\
${ }^{241} \mathrm{Am}$ & $\mathrm{aCi} / \mathrm{m}^{3}$ & 2.1 & 478.2 & 1,900 & 25.2 \\
${ }^{234} \mathrm{U}$ & $\mathrm{aCi} / \mathrm{m}^{3}$ & 35.6 & 64.5 & 7,700 & 0.8 \\
${ }^{235} \mathrm{U}$ & $\mathrm{aCi} / \mathrm{m}^{3}$ & 2.2 & 3.7 & 7,100 & $<0.1$ \\
${ }^{238} \mathrm{U}$ & $\mathrm{aCi} / \mathrm{m}^{3}$ & 24.7 & 50.6 & 8,300 & 0.6 \\
\hline
\end{tabular}

"LANL 1997b:Tables 4-4-4-10, 80-93.

'Each EPA limit equals the amount of radioactivity that would have to be released into the atmosphere to cause the general public to receive an effective dose equivalent of 10 millirem per year (LANL 1997b:Table 41, 75).

\subsubsection{Perimeter Monitoring}

${ }^{238} \mathrm{Pu}$. In 1996, the mean annual concentration of ${ }^{238} \mathrm{Pu}$ recorded at perimeter locations, including numerous stations in Los Alamos and White Rock, was $0.2 \mathrm{aCi} / \mathrm{m}^{3}$, which is equivalent to an effective dose equivalent of less than 0.001 mrem per year. At the monitoring station recording the highest offsite concentration, Royal Crest Trailer Court, the mean annual concentration was $1.0 \mathrm{aCi} / \mathrm{m}^{3}$, which is equivalent to an effective dose equivalent of less than 0.01 mrem per year (LANL 1997b:Table 4-5, 82).

${ }^{239} \mathrm{Pu}$. In 1996, the mean annual concentration of ${ }^{239} \mathrm{Pu}$ recorded at perimeter locations was $1.0 \mathrm{aCi} / \mathrm{m}^{3}$, which is equivalent to an effective dose equivalent of less than 0.01 mrem per year. At the monitoring station recording the highest offsite concentration, the Los Alamos Airport, the mean annual concentration was $2.9 \mathrm{aCi} / \mathrm{m}^{3}$, which is equivalent to an effective dose equivalent of approximately 0.01 mrem per year (LANL 1997b:Table 4-6, 84).

Tritium. Tritium is released by LANL in curie amounts. In addition, tritium is present in the environment as a result of aboveground nuclear weapons tests and is also produced naturally. In 1996, the mean annual concentration recorded at perimeter locations was $1.3 \mathrm{pCi} / \mathrm{m}^{3}$, which is equivalent to an effective dose equivalent of less than 0.01 mrem per year. At the monitoring stations recording the highest offsite concentrations, the McDonald's Restaurant in Los Alamos and the White Rock Church of the Nazarene, the mean annual concentration was $2.2 \mathrm{pCi} / \mathrm{m}^{3}$, which is equivalent to an effective dose equivalent of approximately 0.01 mrem per year (LANL 1997b:Table 4-4, 80). Recently, it has been discovered by LANL that the reporting associated with tritium releases from the laboratory (set forth above) may be underestimating actual tritium levels by a factor of two to three times. In the worst case, the level of tritium released could be as high as five times greater than reported (Eberhart, 1998). At the point of highest offsite concentration, the estimated mean annual concentration would be $11 \mathrm{pCi} / \mathrm{m}^{3}$ (i.e., $2.2 \times 5$ ). This would be equivalent to an effective dose of approximately 0.07 mrem per year.

${ }^{241} \mathrm{Am}$. Americium is released from LANL in microcurie amounts. In 1996, the mean annual concentration of ${ }^{241} \mathrm{Am}$ recorded at perimeter locations was $1.8 \mathrm{aCi} / \mathrm{m}^{3}$, which is less than an effective dose equivalent of approximately 0.01 mrem per year. At the monitoring station recording the highest offsite concentration, Santa $\mathrm{Fe}$, the mean annual concentration was $2.5 \mathrm{aCi} / \mathrm{m}^{3}$, which is equivalent to an effective dose equivalent of approximately 0.01 mrem per year (LANL 1997b:Table 4-7, 86). 
${ }^{234} \mathrm{U}$. All of the isotopes of uranium are released from LANL in microcurie amounts and occur naturally in rocks and soils. In 1996, the mean annual concentration of ${ }^{234} \mathrm{U}$ recorded at perimeter locations was $10.2 \mathrm{aCi} / \mathrm{m}^{3}$, which is equivalent to an effective dose equivalent of approximately $0.01 \mathrm{mrem}$ per year. At the monitoring station recording the highest offsite concentration, Española, the mean annual concentration was $49.1 \mathrm{aCi} / \mathrm{m}^{3}$, which is equivalent to an effective dose equivalent of approximately 0.06 mrem per year (LANL 1997b:Table 4-8, 88).

${ }^{235} \mathrm{U}$. In 1996 , the mean annual concentration of ${ }^{235} \mathrm{U}$ recorded at perimeter locations was $0.9 \mathrm{aCi} / \mathrm{m}^{3}$, which is equivalent to an effective dose equivalent of less than 0.01 mrem per year. At the monitoring station recording the highest offsite concentrations, Española, the mean annual concentration was $3.1 \mathrm{aCi} / \mathrm{m}^{3}$, which is equivalent to an effective dose equivalent of less than 0.01 mrem per year (LANL 1997b:Table 4-9, 90).

${ }^{238} \mathrm{U}$. In 1996 , the mean annual concentration of ${ }^{238} \mathrm{U}$ recorded at perimeter locations was $10.5 \mathrm{aCi} / \mathrm{m}^{3}$, which is equivalent to an effective dose equivalent of approximately 0.01 mrem per year. At the monitoring station recording the highest offsite concentration, Jemez Pueblo-Riverside, the mean annual concentration was $38.3 \mathrm{aCi} / \mathrm{m}^{3}$, which is equivalent to an effective dose equivalent of approximately 0.05 mrem per year (LANL 1997b:Table 4-10, 92).

In all cases, the maximum individual effective dose equivalents attributable to exposure from airborne LANL emissions were below the EPA limits. Measurements of LANL stack emissions during 1996 totaled 13,790

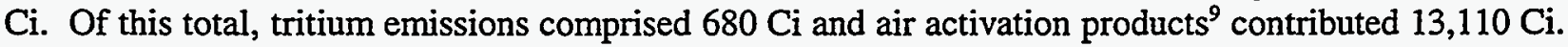
Combined airborne emissions of radioactive materials such as plutonium, uranium, and americium were less than 0.5 Ci (LANL 1997b:64).

In 1996, emissions of radionuclides from TA-55 were as presented in Table 5-2. Exposure to these releases was estimated by the CAP88, EPA's dose assessment model, to result in an effective dose equivalent of 0.000364 mrem to the offsite maximally exposed individual (MED) (Jacobson 1997:6, 20).

Table 5-2. Releases of Radionuclides from TA-55 in 1996

\begin{tabular}{cc}
\hline Radionuclide & Sampled Release (Ci) \\
\hline Americium 241 & $3.1 \times 10^{-8}$ \\
Plutonium 238 & $2.5 \times 10^{-9}$ \\
Plutonium 239 & $8.6 \times 10^{-8}$ \\
Uranium 234 & $2.6 \times 10^{-8}$ \\
Uranium 238 & $2.9 \times 10^{-8}$ \\
Thorium 234 & $2.9 \times 10^{-8}$ \\
Protactinium 234 & $2.9 \times 10^{-8}$ \\
Tritium & $3.1 \times 10^{+1}$ \\
\hline
\end{tabular}

Source: Jacobson 1997:14.

Individuals are constantly exposed to radiation as a result of cosmic radiation from space and natural radiation from radionuclides in the environment (mainly radon). In addition, as people inhale or absorb radionuclides from natural sources they are collected within the body and produce radiation as they decay.

9 Nuclear reactions with air cause the formation of air activation products. These include radioisotopes of carbon, nitrogen, and oxygen that have a half-life of seconds up to 20 minutes. The major source of these products at LANL has been as a result of airbome emissions from the Los Alamos Neutron Science Center (LANL 1997b:67). 
Table 5-3 shows the effective dose equivalent for people living in Los Alamos and White Rock as a result of existing sources of radiation.

Table 5-3. Estimated Background Dose from Natural and Man-Made Sources of Radiation (mrem/year)

\begin{tabular}{lcc} 
& \multicolumn{3}{c}{ Man-Made Sources of Radiation (mrem/year) } \\
\hline Radon & 200 & White Rock \\
Cosmic (corrected for shielding) & 120 & 200 \\
Self-irradiation & 40 & 100 \\
Total effective background dose & 360 & 40 \\
\hline
\end{tabular}

Source: LANL 1997b:50.

To estimate the dose above background levels received by the public as a result of penetrating radiation from LANL activities, a network of thermoluminescent dosimeters has been installed around LANL and surrounding areas. During 1996 the maximum dose, or the ninety-fifth percentile value, was equivalent to 13.3 mrem. This dose was 13.3 percent of DOE's public dose limit of $100 \mathrm{mrem}$ effective dose equivalent from all pathways. The median value (fiftieth percentile) for this dose is $4.3 \mathrm{mrem}$; this dose is approximately one percent of the total annual dose received by persons living around LANL from all sources of radiation as shown in Table 5-2 (LANL 1997b:51). Based on the population living within 80 kilometers (50 miles) of LANL, it is estimated that the total dose to the public in 1996 was 1.2 person-rem. (LANL 1997b:54).

Workers in TA-55 would be expected to receive an additional dose above that received by the general public as a result of their work with nuclear materials. Exposure pathways to LANL workers during normal operations may include inhaling the workplace atmosphere, drinking potable water that could somehow become contaminated, and possibly other contacts with hazardous materials associated with their work assignments. Workers are protected from hazards specific to the workplace through appropriate training, protective equipment, monitoring, and management controls. Although the Federal exposure limit for radiation workers is 5 rem per year (DOE 1997d:sec. 835.202), DOE's Administrative Control Level is 2 rem per year (DOE 1994c:2-3). All facilities at LANL are operating in accordance with the As Low As Reasonably Achievable (ALARA) program to limit worker doses to the extent possible. The average dose that badged workers (radiation workers) in TA-55 received in 1997 was 175 mrem per worker or 3.5 percent of the Federal exposure limit (Graf 1998).

\subsubsection{Worker and Public Safety}

LANL workers are protected by adherence to Occupational Safety and Health Administration and EPA occupational health standards that limit workplace concentrations of potentially hazardous chemicals. Appropriate monitoring, which reflects the frequency and amounts of chemicals utilized in the operation processes, ensures that these standards are not exceeded. Additionally, DOE requirements ensure that conditions in the workplace are as free as possible from recognized hazards that cause or are likely to cause illness or physical harm.

Each DOE site has established an emergency management program that would be activated in the event of an accident. This program has been developed and maintained to ensure adequate response for most accident conditions and to provide response efforts for accidents not specifically considered. The emergency management program incorporates activities associated with emergency planning, preparedness, and response. The LANL Emergency Preparedness Plan is designed to minimize or mitigate the impact of any emergency on the health and safety of employees and the public. 


\subsubsection{Waste Management}

LANL routinely produces waste in the following categories: TRU waste, LLW, MLLW, and hazardous waste, that could be impacted by the proposed Pit Disassembly and Conversion Demonstration.

\subsubsection{Transuranic Waste}

TRU waste is generally characterized as waste that is contaminated with alpha-emitting transuranic isotopes with atomic numbers greater than 92 and half-lives greater than 20 years, in concentrations greater than $100 \mathrm{nCi} / \mathrm{g}$ at the time of assay. TRU waste generated at TA-55 is taken to TA-54, placed in drums, certified, and stored for ultimate disposal at the Waste Isolation Pilot Plant (WIPP) in Carlsbad, New Mexico. Most of LANL's TRU waste is currently stored on asphalt pads. In 1996, LANL generated about 81 cubic meters of TRU waste (LANL 1997i:4).

\subsubsection{Low-Level Waste}

LLW contains some radioactivity but not enough to be classified as high-level waste (HLW), TRU waste, or spent nuclear fuel. After being generated at TA-55, liquid LLW is transferred by a stainless steel pipeline to the Radioactive Liquid Waste Treatment Facility at TA-50 for treatment. The waste water is treated by lime/sulfate precipitation. The treated water is discharged under LANL's NPDES permit. The remaining sludge is dewatered and sent to TA-54 for disposal as LLW. Approximately 521 cubic meters of solid LLW and 11 cubic meters of solid LLW that resulted from treating liquid LLW was generated by LANL in 1996 (LANL 1997i:4). This waste is buried in TA-54, Area G, in pits and shafts designed specifically for this purpose.

\subsubsection{Mixed Low-Level Waste}

MLLW contains both hazardous (as defined and regulated by the Resource Conservation and Recovery Act (RCRA)) and low-level radioactive components. ${ }^{10}$ MLLW generated at TA-55 is placed in interim storage at TA-55 and collected by LANL waste management personnel. It is then stored at TA-54, Areas L and G, pending the availability of offsite commercial treatment. About 7 cubic meters of MLLW was generated by LANL in 1996 (LANL 1997i:4).

\subsubsection{Hazardous Waste}

Hazardous wastes are listed as such in RCRA regulations or defined as hazardous wastes because they exhibit at least one of the following characteristics: (1) ignitability, (2) corrosivity, (3) reactivity, or (4) toxicity. No disposal facility for hazardous waste exists at LANL. Hazardous wastes are shipped off the site for further treatment and disposal at designated facilities in accordance with RCRA. In 1996, LANL generated approximately 90,000 kilograms of hazardous waste from routine operations (LANL 1997i:4).

\footnotetext{
${ }^{10}$ In accordance with the Federal Facility Compliance Act, LANL has developed a Site Treatment Plan that covers management of all mixed waste at LANL. The State of New Mexico Environment Department issued a compliance order in the Site Treatment Plan for Mixed Waste in October 1995. The compliance order addresses land disposal restricted mixed waste. For mixed waste with identified treatment technologies, the plan provides a schedule for submitting permit applications, entering into contracts, initiating construction, conducting system testing, starting operations, and processing mixed waste. For mixed waste without an identified treatment technology, the plan includes a schedule for identifying and developing technologies, identifying the funding requirements for $R \& D$, submitting treatability study notifications, and submitting $R \& D$ permit applications.
} 


\subsubsection{Socioeconomics}

Approximately 10,000 people are employed at LANL in permanent special programs and contractor activities. Eighty-eight percent of all LANL employees reside in a three-county area (Los Alamos, Arriba, and Santa $\mathrm{Fe}$ ), and more than half of the Los Alamos County employees reside in the unincorporated communities of Los Alamos and White Rock. This three-county area has been designated the region of influence (ROI) for the regional economic area (REA) in which LANL is located. The unemployment rate in the REA was 6.2 percent, which was about the same as the overall unemployment rate in New Mexico of 6.3 percent (LANL 1997a:1; DOE 1996a: 3-326).

LANL has a cumulative economic impact on the ROI of more than $\$ 3.5$ billion annually, making it the dominant economic force in northern New Mexico. The region's per capita income of $\$ 17,689$ in 1993 was approximately 8.2 percent higher than New Mexico's per capita income of \$16,346 (LANL 1997a:1; DOE 1996a: 3-326).

In 1994 , the ROI population totaled 166,788 . From 1980 to 1994 , the ROI population increased by 36.6 percent, compared to 26.9 percent in New Mexico, with Santa Fe County experiencing the largest growth at 48.6 percent. In 1994, seven schools provided public education in the LANL ROI. City, county, and state law enforcement agencies provided police protection to the ROI residents. Fire protection services were provided by 800 paid and volunteer firefighters in 1995. Four hospitals served the ROI in 1994 (DOE 1996a: 3-326, 3-332).

Regional transportation routes provide access to LANL with vehicular access provided by New Mexico Route 502 to the east and Route 4 to the west. There are no planned road improvement projects within one to two years that would affect LANL. While there is no public bus service to LANL, there is non-profit bus service between White Rock, Los Alamos and LANL (DOE 1996a:3-332).

\subsubsection{Environmental Justice}

The 1990 minority population, residing within 80 kilometers (50 miles) of LANL, was estimated to be 53.9 percent of the total population. Population data for 1990 was extracted from data published by the U.S. Bureau of the Census for the 1990 census (DOC 1992:Tables P-12, P-121). Minority populations are projected to make up 55.6 percent of the total population in 2001. Projected populations for the year 2001 were obtained from the Bureau of the Census state population projects (Campbell 1997:4-24). It was assumed that minority and majority populations residing within 80 kilometers of LANL would increase at the same rates as projected increases for the statewide minority and majority populations.

Estimates of low-income persons residing in the potentially affected area is shown in Table 5-4 (DOC 1992:Table P-121). In this table, the low-income population is comprised of persons residing within 80 kilometers (50 miles) of the site whose income is less than the poverty threshold (CEQ 1996:app. A, 16). The percentage of the population with income below the poverty threshold exceeds the 13.3 national average.

Table 5-4. Low-Income Persons Residing Within 80 Kilometers of LANL

\begin{tabular}{cccc}
\hline Site & $\begin{array}{c}\text { Total Population } \\
\text { (Thousands) }\end{array}$ & $\begin{array}{c}\text { Low-Income } \\
\text { Population } \\
\text { (Thousands) }\end{array}$ & $\begin{array}{c}\text { Percent } \\
\text { Low-Income } \\
\text { Population }\end{array}$ \\
\hline LANL & 214.3 & 31.5 & 14.7 \\
\hline
\end{tabular}




\subsection{POTENTIAL ENVIRONMENTAL IMPACTS}

\subsection{Impacts Related to the Proposed Action}

\subsubsection{Water Quality Impacts}

Under the proposed action, noncontact water would be used to cool processing equipment. Wastewater discharges would be into the industrial waste lines at PF-4. It is estimated that less than 189 liters (50 gallons) of noncontact water would be discharged from PF-4 as a result of the proposed demonstration. Additionally, a small amount of process water would be-used as part of the decontamination module. This process water, less than 100 liters (26 gallons) per year, would be handled in accordance with LANL's procedures for the treatment and disposal of liquid LLW. The overall compliance for sanitary and industrial discharges during 1996 was 98.8 percent and 97.9 percent, respectively (LANL 1997b:26). The proposed action is not expected to affect these compliance rates because the amount of water that would be used in the process is so small. No increased release of radionuclides is expected by liquid pathways as a result of the proposed demonstration.

\subsubsection{Air Quality Impacts}

As a part of this demonstration, it is projected that small amounts of plutonium and americium would be released into the atmosphere, as shown in Table 6-1. It is also projected that small amounts of tritium would be released from SRL operations on the plutonium that is subsequently transferred to the demonstration; these tritium releases, while not a part of the demonstration activities, are also shown in Table 6-1 to capture the total cumulative impact of the demonstration activities, support activities, and precursor activities at LANL. The MEI is estimated to receive an effective dose equivalent of $0.043 \mathrm{mrem}$ per year from the demonstration and a total dose from all site operations of 4.3 mrem per year.

Table 6-1. Estimated Annual Radionuclide Releases Under the Proposed Demonstration

\begin{tabular}{lccc}
\hline Radionuclide & $\begin{array}{c}\text { Estimated Annual } \\
\text { Releases from } \\
\text { Demonstration } \\
\text { (in curies) }\end{array}$ & $\begin{array}{c}\text { Annual Releases at } \\
\text { LANL in 1996 } \\
\text { (in curies) }\end{array}$ & $\begin{array}{c}\text { Estimated Releases as } \\
\text { a Percent of Annual } \\
\text { Releases at LANL }\end{array}$ \\
\hline Total plutonium & $1.0 \times 10^{-7}$ & $2.3 \times 10^{-5}$ & $<1$ \\
Americium 241 & $2.3 \times 10^{-8}$ & $1.3 \times 10^{-6}$ & $<2$ \\
Tritium & 69 & $6.8 \times 10^{2}$ & 10 \\
Total uranium & None & $3.9 \times 10^{-5}$ & NA \\
'LANL 1997b:102-103; Jacobson, 1998. & & \\
'Estimated release as part of SRL operations. & & \\
Note: NA, not applicable. &
\end{tabular}

The pit disassembly and conversion process proposed to be demonstrated does not require the use of hazardous chemicals or other potentially hazardous compounds that could be released into the atmosphere in the course of normal operations. There is not expected to be any airborne releases of beryllium as a result of the demonstration. Any hazardous compounds released would be very small quantities related to routine, cleaning operations connected with the demonstration. 


\subsubsection{Radiological Impacts}

The radiological impacts of normal operations associated with the proposed action were calculated using Version 1.485 of the Hanford Environmental Dosimetry System (GENII) ${ }^{11}$ computer code (PNL 1988). Sitespecific and technology-specific input data were used, including location, meteorology, population, food production and consumption, and source terms. Dose assessments were performed for members of the general public surrounding LANL and for workers who would be involved with the proposed operations.

To calculate the doses, the projected releases were extrapolated based on the data developed for the SPD Draft EIS (LANL 1997d:62). As shown in that report, the dominant radioactive emission from pit disassembly and conversion activities is tritium. Using this information, it was estimated that approximately 69 curies of tritium would be released annually as a result of SRL operations that are not a part of the demonstration project. A similar method was used to estimate the radioactive emissions from the demonstration although they are all relatively small in comparison to tritium (see Table 6-1).

Dose assessments for members of the public were performed for three different types of receptors considered in this EA: the offsite MEI, the offsite average exposed individual, and the general population living within 80 kilometers (50 miles). The MEI was assumed to be located at a position that would yield the highest impacts during normal operations. In the case of the pit demonstration, this would be an individual in the Royal Crest Trailer Court in Los Alamos, which is located at the northern perimeter of LANL above TA-55. For total LANL site operations, this would be an individual near LANL's East Gate. To bound the analyses, the doses to both MEIs were added to provide a hypothetical worst case dose.

The annual average individual worker dose directly associated with the proposed action was estimated at 750 mrem per year. ${ }^{12}$ Subsequent health risks (i.e., latent cancer fatalities) were calculated for the aforementioned groups by using risk estimators established in the National Academy of Sciences and National Research Council's 1990 Health Effects of Exposure to Low Levels of lonizing Radiation BEIR V Report.

The pit disassembly and conversion process involves the use of hydrogen, oxygen, and nitrogen, and inert gases such as argon and helium. All of these gases would be fed into the gloveboxes under controlled conditions. Gases exiting the gloveboxes would be filtered through a series of HEPA filters to capture the majority of the radionuclides released during the demonstration. However, a small amount of radionuclides would be expected to enter the atmosphere, if the proposed action were undertaken. As shown in Table 6-1, these releases are estimated to be a small fraction of the radionuclides released by LANL in any given year.

The largest releases are estimated to be approximately 69 curies of tritium each year from SRL operations which are not part of this demonstration. This amount represents about 10 percent of the total expected

"The GENII computer code was developed under a stringent Quality Assurance plan based on the American National Standard Institute standard for National Quality Assurance-1, as implemented in the Pacific Northwest Laboratory Quality Assurance Manual PNL-MA-70. All steps of the code development have been documented and tested. An external peer review of the entire code package was conducted in 1988. The use of GENII has been approved by EPA.

12 This estimated radiation worker dose was developed based on several factors. Because the proposed pit disassembly and conversion demonstration has never been performed before, the worker dose could not be based on actual or historical worker doses. Therefore, the worker dose had to be estimated based on a review of worker doses from similar operations, process knowledge regarding amounts of materials and potential for worker exposure, and consideration of planned operational features designed to reduce worker exposure. As shown in Table 6-4, similar pit disassembly activities have resulted in average worker doses of $456 \mathrm{mrem} /$ year. Although improvements planned for this demonstration are expected to result in reductions in average worker doses, in order to provide a conservative estimate, a radiation worker dose of $750 \mathrm{mrem} / \mathrm{year}$ was used. 
tritium releases for LANL. ${ }^{13}$ It is expected that total releases would continue to be lower than either the EPA limit or past releases from LANL. Even at the 1995 levels, the resulting maximum concentration measured at any of LANL's numerous offsite monitoring stations was less than one percent of the EPA limit (LANL 1996a:84).

Table 6.2 shows that the proposed demonstration should not affect LANL's ability to continue to meet the guidelines included in 40 CFR 61.93(b)(5)(iv) Subpart H-National Emission Standards for Emissions of Radionuclides Other Than-Radon from-Department of-Energy Facilities (EPA 1997). In the case of the proposed demonstration at LANL, the MEI would be located in the Royal Crest Trailer Court. The 1996 maximum offsite concentrations at this site were used as a conservative baseline for making the comparison with 40 CFR.61. Although.it.is highly unlikely that the-maximum.would be seen over the course of a full year it was used as the base to project what the affect of the demonstration would be even if the levels were as high as the maximum. Based on this projection, it is estimated that the cumulative total for all radionuclides, with the proposed demonstration included, would be less than two percent of the EPA guidelines.

Table 6-2. Projected Releases of Radionuclides Versus EPA Concentration Levels in 40 CFR 61

\begin{tabular}{lcccc}
\hline Radionuclide & $\begin{array}{c}\text { 1996 Maximum } \\
\text { Offsite Concentration at } \\
\text { Location of MEI }\end{array}$ & $\begin{array}{c}\text { Projected Maximum } \\
\text { Offsite Concentration } \\
\text { with Demonstration }\end{array}$ & $\begin{array}{c}\text { EPA } \\
\text { Concentration } \\
\text { Levels }\end{array}$ & $\begin{array}{c}\text { Projection/ } \\
\text { EPA Levels }\end{array}$ \\
\hline Tritium $\left(\mathrm{pCi} / \mathrm{m}^{3}\right)$ & 15.0 & 16.52 & 2100 & 0.0079 \\
${ }^{238} \mathrm{Pu}\left(\mathrm{aCi} / \mathrm{m}^{3}\right)$ & 2.8 & 2.81 & 2000 & 0.0014 \\
${ }^{239} \mathrm{Pu}\left(\mathrm{aCi} / \mathrm{m}^{3}\right)$ & 2.3 & 2.31 & 1500 & 0.0015 \\
${ }^{241} \mathrm{Am}\left(\mathrm{aCi} / \mathrm{m}^{3}\right)$ & 3.3 & 3.36 & 1900 & 0.0018 \\
${ }^{234} \mathrm{U}\left(\mathrm{aCi} / \mathrm{m}^{3}\right)$ & 14.4 & 14.4 & 7700 & 0.0019 \\
${ }^{235} \mathrm{U}\left(\mathrm{aCi} / \mathrm{m}^{3}\right)$ & 1.90 & 1.90 & 7100 & 0.0003 \\
${ }^{238} \mathrm{U} \cdot\left(\mathrm{aCi} / \mathrm{m}^{3}\right)$ & 16.6 & 16.6 & 8300 & 0.0020 \\
$\mathrm{Cumulative}$ Total & & & & 0.0168 \\
\hline
\end{tabular}

${ }^{3}$ LANL 1997b: Tables 4-4 - 4-10, 80-93.

b EPA 1997: App E, Table 2.

Radiological impacts on the average and maximally exposed members of the public resulting from normal operations of the proposed action are presented in Table 6-3. Also included in the table are the dose to the population within 80 kilometers (50 miles) in 2000 (mid-year of projected operations for the proposed demonstration), and the projected annual number of latent cancer fatalities in this population. To put operational doses into perspective, comparisons with doses from natural background radiation are also included.

The dose to the maximally exposed member of the public from annual operation of the proposed action would be 0.043 mrem. The corresponding annual risk of latent fatal cancer to this individual would be $2.2 \times 10^{-8}$. That is, the estimated probability of this person dying of cancer at some point in the future from radiation exposure associated with the demonstration is less than three in 100 million. The impacts on the average individual would be less.

${ }^{13}$ In 1996, LANL released 680 curies of tritium into the atmosphere during site operations (LANL 1997b: 61). 
Table 6-3. Potential Radiological Impacts to the Public at LANL

\begin{tabular}{lccc}
\hline \multicolumn{1}{c}{ Receptor $^{\mathrm{a}}$} & $\begin{array}{c}\text { Pit Disassembly } \\
\text { Demonstration }\end{array}$ & $\begin{array}{c}\text { Total Site Without } \\
\text { Pit_Disassembly } \\
\text { Demonstration }\end{array}$ & $\begin{array}{c}\text { Total Site With } \\
\text { Pit_Disassembly } \\
\text { Demonstration }\end{array}$ \\
\hline $\begin{array}{l}\text { Maximally exposed individual } \\
\text { member of the public }\end{array}$ & & & \\
$\begin{array}{l}\text { Annual dose (mrem) } \\
\text { Percent of natural background }\end{array}$ & 0.043 & 4.30 & 4.34 \\
$\quad \begin{array}{l}\text { Annual latent cancer fatalities } \\
\text { Population within 80 kilometers }\end{array}$ & 0.0123 & 1.23 & 1.24 \\
for Year 2000 & $2.2 \times 10^{-8}$ & $2.15 \times 10^{-6}$ & $2.17 \times 10^{-6}$ \\
Annual dose (person-rem) & 0.016 & & \\
$\begin{array}{l}\text { Percent of natural background } \\
\text { b }\end{array}$ & $1.8 \times 10^{-5}$ & 1.20 & 1.22 \\
$\quad \begin{array}{l}\text { Annual latent cancer fatalities } \\
\text { Average individual within }\end{array}$ & $8.0 \times 10^{-6}$ & $1.32 \times 10^{-3}$ & $1.34 \times 10^{-3}$ \\
80 kilometers & & $6.00 \times 10^{-4}$ & $6.08 \times 10^{-4}$ \\
Annual dose (mrem) & & & \\
Annual latent cancer fatalities & $3.1 \times 10^{-11}$ & $4.61 \times 10^{-3}$ & $4.67 \times 10^{-3}$ \\
\hline
\end{tabular}

"Presented impacts to these receptors are associated with releases to the air. There would be no liquid releases associated with the pit disassembly demonstration.

'The annual natural background radiation level at LANL is $349 \mathrm{mrem}$ for the average individual; the population within 80 kilometers in 2000 would receive 90,900 person-rem.

'Obtained by dividing the population dose by the number of people projected to live within 80 kilometers of LANL $(260,360)$ in 2000.

Source: LANL 1997b: GENII model results (Version 1.485).

As a result of annual facility operations, the total population dose would be 0.016 person-rem. The corresponding annual number of latent cancer fatalities in this population would be $8.0 \times 10^{-6}$. The Environmental Surveillance and Compliance at Los Alamos during 1996 report (LANL 1997b:51, 54) states that an annual dose of 4.3 mrem to a MEI and a collective dose of 1.2 person-rem to the surrounding population within 80 kilometers (50 miles) resulted from all 1996 LANL operations. Assuming a similar total site operational status in 2000 , radiological impacts associated with the proposed action would increase LANL total site impacts by a small percentage (1.0 percent for the MEI, 1.3 percent for the surrounding population, and 1.3 percent for the average individual).

Doses to involved workers from normal operations, including receiving and staging of the pits, are presented in Table 6-4; involved workers are defined as those directly associated with pit disassembly activities. Under the proposed action, the estimated annual average dose to pit disassembly workers would be $750 \mathrm{mrem}$.

Table 6-4. Potential Radiological Impacts to Plutonium Workers at LANL

\begin{tabular}{lcc}
\hline \multicolumn{1}{c}{ Receptor } & Pit Disassembly & $\begin{array}{c}\text { Other Pit Disassembly } \\
\text { Activities }\end{array}$ \\
\hline Involved workers ${ }^{2}$ & & \\
Average worker dose (mrem/yr) & 750 & 456 \\
Annual risk of latent cancer fatalities & $3.0 \times 10^{-4}$ & $1.8 \times 10^{-4}$ \\
Total dose (person-rem/yr) & 90 & 55 \\
Total annual latent cancer fatalities & 0.036 & 0.022 \\
\hline
\end{tabular}

${ }^{2}$ One hundred and twenty badged workers would be required for pit disassembly and conversion facility operations. The radiological limit for an individual worker is 5,000 mrem/year. However, the maximum dose to a worker involved with operations would be kept below the DOE Administrative Control Level of 2,000 mrem per year. An effective ALARA program would ensure that doses would be reduced to levels that are as low as is reasonably achievable. 
The annual dose received by the plutonium workers who would perform these activities would increase by 35 person-rem to 90 person-rem. The annual risk of latent cancer fatalities to involved workers as a result of the doses received from the demonstration would be $3.0 \times 10^{-4}$ or 3 chances in 10,000 . Doses to individual workers would be kept to minimal levels by current administrative policies, exposure monitoring, and the ALARA program.

\subsubsection{Accident Impacts}

The pit disassembly and conversion process proposed to be demonstrated would consist of a number of distinct, sequential processes: bisection and disassembly, oxidation, gallium removal, canning, electrolytic decontamination, and nondestructive assay, each performed in separate gloveboxes. Another glovebox would contain the conveyor system that would transfer the plutonium between the gloveboxes. LANL Process Hazard Analyses serve as the basis for evaluating the potential accidents associated with the proposed action. These Hazard Analyses, intended to provide a screen to identify safety-class equipment requirements, are significantly conservative; they may not take credit for all process or control barriers to an abnormal event or its potential consequences in evaluating consequence likelihoods. For this reason, they form a conservative basis for evaluating accident impacts for this EA. Considering the low-magnitude of the predicted impacts, no effort was taken to further refine the risk evaluations for this EA.

The spectrum of plausible accidents and abnormal events associated with the proposed action were evaluated to identify those with the highest radiological impacts. Because of the physical separation of the various modules in the process, the potential accidents and abnormal events for each step were evaluated independently. It is important to note that both the type and frequency of plausible accidents for the proposed action depend on the specific process involved; for example, processes involving both hydrogen and oxygen along with plutonium would have significantly different risks than would processes involving handling or machining of plutonium components in an inert atmosphere.

The modules associated with the pit disassembly and conversion process at TA-55 have been the subject of Process Hazard Analysis (PrHA) (LANL 1998; LANL 1997c; LANL 1997e; LANL 1997f; LANL 1997g; LANL 1997h). For these PrHAs, the dose to the public was calculated using the Gaussian dispersion model MACCS2. ${ }^{14}$ Weather sampling was based on $95^{\text {th }}$ percentile data.

Each hazard was evaluated as to the severity of the consequences and qualitatively assigned a severity category. The severity categories used in the evaluation of accidents and abnormal events are presented in Table 6-5.

14 The MELCOR Accident Consequence Code System 2 (MACCS2) computer code (SNL 1997, Chanin 1997) was used for the Process Hazard Analyses referenced in this EA because it is a superior dose consequence analysis code. The National Research Council's Committee on the Biological Effects of Ionizing Radiation (BEIR) has prepared a series of reports to advise the Federal government on the health consequences of radiation exposures. The latest of these reports, Health Effects of Exposure to Low Levels of Ionizing Radiation BEIR V, published in 1990, provides the most current estimates for excess mortality from leukemia and cancers other than leukemia expected to result from exposure to ionizing radiation (NAS/NRC 1990). The BEIR $V$ models were developed for application to the U.S. population and are implemented in the radiological consequence model (MACCS2) used in the accident analyses. MACCS2 employs methodology that allows the user to account for the source term contribution of short-term resuspension of deposited material, uses an entire year's worth of actual LANL weather and reports the mean value and the distribution of values accounts for the integrated population exposure (and the resulting latent cancer fatality risk) from the LANL workforce population, and uses actual LANL meteorology. In addition to ad hoc verification efforts of beta-test user groups, the University of New Mexico has completed a formal independent verification study of the MACCS2 code package. The results of this verification study will be published in a forthcoming report. 
Table 6-5. Consequences Severity Categories

\begin{tabular}{|c|c|c|c|}
\hline Category & Public & Worker & Environment \\
\hline A & Immediate health effects & Loss of life & $\begin{array}{l}\text { Significant offsite contamination } \\
\text { requiring cleanup }\end{array}$ \\
\hline B & Long-term health effects & $\begin{array}{l}\text { Severe injury or disability } \\
\text { Radiation uptake or dose } \\
\text { causing temporary radiation } \\
\text { worker restriction }\end{array}$ & $\begin{array}{l}\text { Moderate-to-significant onsite } \\
\text { contamination } \\
\text { Minor offsite contamination }\end{array}$ \\
\hline $\mathrm{C}$ & $\begin{array}{l}\text { Irritation or discomfort } \\
\text { but no permanent } \\
\text { health effects }\end{array}$ & $\begin{array}{l}\text { Lost-time injury but no } \\
\text { disability } \\
\text { Radiation uptake or dose } \\
\text { causing temporary radiation } \\
\text { worker restriction }\end{array}$ & $\begin{array}{l}\text { Significant contamination of } \\
\text { originating facility } \\
\text { Minor onsite contamination } \\
\text { No offsite contamination }\end{array}$ \\
\hline D & $\begin{array}{l}\text { No significant offsite } \\
\text { impact }\end{array}$ & $\begin{array}{l}\text { Minor or no injury and no } \\
\text { disability }\end{array}$ & $\begin{array}{l}\text { Minor or no contamination of } \\
\text { originating facility } \\
\text { No onsite contamination } \\
\text { No offsite contamination }\end{array}$ \\
\hline
\end{tabular}

Source: LANL 1997c:17.

In assessing the significance of an accident or abnormal event, the frequency of the event must be considered as well as the consequences. Table $6-6$ presents the Consequence Likelihood Categories used for the evaluation of hazards associated with the proposed Pit Disassembly and Conversion Demonstration.

Table 6-6. Consequence Likelihood Categories

\begin{tabular}{|c|c|}
\hline Frequency & Definition \\
\hline $\begin{array}{c}\text { I } \\
(1 \text { to } 0.1)\end{array}$ & $\begin{array}{l}\text { Normal Operations: frequency between once per year and } \\
1 \text { in } 10 \text { operating-years or at least once in } 10 \text { similar } \\
\text { facilities operated for } 1 \text { year }\end{array}$ \\
\hline $\begin{array}{c}\text { II } \\
(0.1 \text { to } .01)\end{array}$ & $\begin{array}{l}\text { Anticipated Events: frequency between } 1 \text { in } 10 \text { years and } 1 \\
\text { in } 100 \text { operating-years or at least once in } 100 \text { similar } \\
\text { facilities operated for } 1 \text { year }\end{array}$ \\
\hline$\underset{\left(10^{-2} \text { to } 10^{-4}\right)}{\text { III }}$ & $\begin{array}{l}\text { Unlikely: frequency between } 1 \text { in } 100 \text { years and } 1 \text { in } \\
10,000 \text { operating-years or at least once in } 10,000 \text { similar } \\
\text { facilities operated for } 1 \text { year }\end{array}$ \\
\hline$\underset{\left(10^{-4} \text { to } 10^{-6}\right)}{ }$ & $\begin{array}{l}\text { Very Unlikely: frequency between } 1 \text { in } 10,000 \text { years and } \\
\text { once in } 1 \text { million years or at least once in a million } \\
\text { similar facilities operated for } 1 \text { year }\end{array}$ \\
\hline $\begin{array}{c}V \\
\left(<10^{-6}\right)\end{array}$ & Improbable: frequency of less than once in 1 million years \\
\hline
\end{tabular}

Source: LANL 1997c:18

Due to design requirements based on reducing the impacts of potential accidents, as the consequences of an event increase, the likelihood of that event occurring decreases. As a result, a Severity Category "A" event would normally be expected to have a frequency of IV or V. Risk, which is the product of consequence and frequency, is one way to evaluate an accident or abnormal event. Table 6-7 shows the way risk is ranked for the evaluation of accidents and abnormal events. 
Table 6-7. Risk Ranking Matrix

\begin{tabular}{cccccc}
\hline \multirow{2}{*}{$\begin{array}{c}\text { Severity of } \\
\text { Consequence }\end{array}$} & \multicolumn{5}{c}{ Likelihood of Consequence } \\
\cline { 2 - 6 } & I & II & III & IV & V \\
\hline A & 1 & 1 & 2 & 3 & 3 \\
B & 1 & 2 & $2^{\mathrm{a}}$ & 3 & 4 \\
C & 1 & 3 & 3 & 4 & 4 \\
D & 3 & 4 & 4 & 4 & 4 \\
\hline
\end{tabular}

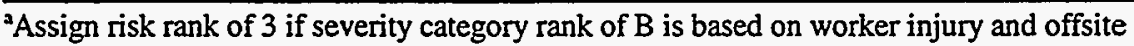
consequences severity is less than $\mathrm{B}$.

Source: LANL 1997c:18.

\subsubsection{Pit Bisection and Disassembly}

After a pit arrives at the pit bisector and disassembly module, it is weighed; tube appendages are cut off; it is re-weighed; and then it is bisected. The bisection is accomplished using a pit bisector (a rotary shearing assembly much like a tube cutter) or a parting lathe. Using the pit bisector, a beveled-edge parting wheel is placed around the waist of the pit and driven inward toward the center of the pit by a servo-driven lead screw while the pit is slowly rotated. A parting lathe, similar to a standard machine shop lathe, may also be used to cut pits. After bisection is complete, the two hemispheres are separated and weighed. Use of the rotary shearing process minimizes cutting waste while the parting lathe results in a small amount of metal shavings.

The principal hazard associated with this module, is the starting of the rotary table before the vacuum hoist is removed, causing the hoist to hit the glovebox window, the loss of glovebox integrity, and a release of contamination to the room. This hazard is a Severity Category " $\mathrm{D}$ " to the public, frequency II, (anticipated), risk-ranked 4 event (LANL 1997c:14-18). The pit is in metallic form during this accident, hence the only room contamination could come from contamination on the surface of the pit, which is small. The PrHA for this module indicates that the accidents associated with this module have less significant consequences than those of other modules.

\subsubsection{Oxidation}

This module converts plutonium from metal to an oxide. In the hydride-oxidation (HYDOX) process, the subassembly is first placed in a vacuum chamber inside the module glovebox. After evacuating the chamber, the subassembly is exposed to hydrogen gas at low pressure and temperature, which converts plutonium to plutonium hydride. Small plutonium hydride particles spall from the surface, falling from the subassembly into a heated crucible. Once the hydride reaction has been established, nitrogen is introduced. Nitrogen readily replaces the hydrogen in the plutonium hydride, creating plutonium nitride and giving off hydrogen gas. The released hydrogen gas then reacts with the remaining plutonium metal in the subassembly, continuing the cycle. Once all the plutonium has been converted to plutonium nitride, the hydrogen gas is removed from the reactor, the reactor is flushed with nitrogen, and the chamber is evacuated. Next, oxygen is introduced to convert the plutonium nitride to plutonium dioxide. Finally, the chamber is purged with argon and cooled. The plutonium dioxide is transferred to a can by a dustless powder transfer system. The can is then moved to the canning module.

Alternatives to the HYDOX process are hydride/dehydride, which converts hydride powder to a plutonium metal ingot, and direct oxidation that converts plutonium metal to an oxide directly. PrHAs for these 
processes were conducted, however, they are not discussed here because the consequences of the HYDOX accidents are more severe and therefore envelope process accident consequences.

Two types of hazards exist for the HYDOX module: those that breach the glovebox barrier and criticality. The glovebox barrier could be breached by a fire that burns the gloves, or a hydrogen deflagration or explosion. A number of vessel and glovebox explosion, deflagration, and fire scenarios were evaluated by the PrHA. The deflagration in the reactor vessel was identified as having the highest potential consequences to the public.

In this scenario (a Severity Category " $\mathrm{C}$ " for the public, frequency III unlikely, risk-ranked 3 event), the pump-down step following the hydride/nitride recycle sequence is bypassed and oxygen is introduced into the vessel. A deflagration occurs when the hydrogen concentration is reduced to the upper flammable limit. This could only occur with a failure of the system vacuum interlock. The material at risk is 2,500 grams of plutonium nitride. To be conservative, the deflagration was assumed to violate the glovebox integrity and it was also assumed the exhaust HEPA filters on the glovebox were ineffective, though no specific physical cause would be expected to result in this condition.

Using airborne release and the respirable clarifying fractions according to the DOE Handbook, Airborne Release Fractions/Rates and Respirable Fractionsfor Nonreactor Nuclear Facilities (DOE 1994a), the 2,500 grams of plutonium nitride would result in a maximum source term from the deflagration of 3.75 grams plutonium in plutonium nitride form. A mitigated accident, where credit is taken for the building's ventilation system including HEPA filters and other features, would result in a source term of $1.4 \times 10^{-8}$ grams of plutonium and a MEI dose at the site boundary, near the Royal Crest Trailer Park, of $2.8 \times 10^{-8} \mathrm{rem}$ (LANL 1998:52).

Workers in the room at the time of the deflagration may be injured by flying glass and other missiles depending on their proximity to the deflagration. The radiological dose that a worker would receive from an accident cannot be accurately estimated because of several factors, such as the workers proximity to the accident and the shielding that might be in place. If the worker was close to or in contact with the radioactive material involved in the accident, the dose received would be much greater than if the worker were at the other side of the room. Likewise the shielding (i.e., walls, gloveboxes) between the worker and the accident greatly impact the dose received. However, workers in the immediate vicinity may be subject to injury or fatalities as a result of such an accident.

Criticality was considered in the PrHA as a possibility from two risk-ranked 3 events, but was not analyzed in detail because the consequences to the public are bounded by the deflagration accident.

\subsubsection{Gallium Removal}

In this module, plutonium dioxide is thermally treated in a furnace that operates with a reducing gas to volatilize gallium and other impurities that may be present. The impurities are then captured in a vacuum trap and the plutonium dioxide is sent on to the canning module. Possible accidents in this module include fire, a deflagration, or explosion. However, because there would not be any flammable materials present in this module, none of these accidents were considered plausible. Therefore, the consequences of these accidents were not evaluated separately and are considered to be enveloped by the HYDOX accident discussed in Section 6.1.4.2.

\subsubsection{Canning}

In this module, plutonium metal or plutonium dioxide is received in a can that is placed inside a stainless steel inner can, the lid is welded in place with a full penetration weld, the weld is visually inspected, and the 
can is leak tested with helium. The inner can is then sent to the decontamination module, where it is decontaminated and placed in an outer can. The outer can is then placed inside a bell chamber that is filled with the inert gas, helium. The outer can is welded with a full penetration weld, the weld is visually inspected, and the can is leak tested. Upon successful testing, the cans are sent to the nondestructive assay module.

Based on rigorous drop and crush tests performed on these cans, there are no accidents associated with this module that are expected to generate significant offsite consequences, that is, all of the accidents are a Consequence Severity Category " $D$ " for the public and all are frequency III or IV, and risk-ranking of 3 or lower. (LANL 1997f:19).

\subsubsection{Electrolytic Decontamination}

This module removes radioactive contamination from the outside of a sealed can by rinsing the can with a sodium sulfate solution and establishing an electric potential across the fluid and can. This electrolytic process removes a small amount of the can material (stainless steel) as well as the contamination. After flushing and drying, the can is monitored for alpha contamination, weighed and, if contamination-free, would be released from the glovebox line so it can undergo nondestructive assay in the next module.

The principal hazard of this module is deflagration of hydrogen from the disassociation of water during electrolytic decontamination. The hydrogen deflagration accident, ignited by a spark from the direct current power, was analyzed for the glovebox, the electrolyte tank, and the decontamination chamber, all riskranked 3, frequency level III and consequence $C$. The hydrogen detection system is assumed to fail although the process control system does shut down the system. The deflagration in the electrolyte tank and the decontamination chamber is inconsequential due to the small space available for hydrogen accumulation. In the glovebox, the lower flammable limit ( 4 percent hydrogen) could be reached in approximately 2.5 hours if the compressed air and ventilation system were off. A hydrogen deflagration of this amount of hydrogen would injure workers with broken glass and could rupture ear drums, but fatalities are not considered likely. Consequences to the public from such an accident are enveloped by the deflagration accident discussed in Section 6.1.4.2 (LANL 1997h:22).

\subsubsection{Nondestructive Assay}

This module uses a calorimeter, a gamma ray isotopic system, a segmented gamma scanner, and an active/passive neutron multiplicity counter to assay the contents of the cans that come out of the decontamination module. The calorimeter measures the heat output of the sample, while the gamma ray isotopic measuring system determines the plutonium isotopic distribution, americium fraction, uranium/plutonium ratio, and neptunium/plutonium ratio. This information would be combined with the calorimetry data (or the neutron counting data) to yield the mass of plutonium. The neutron counter data would be used primarily when the masses of the sample material are low. Cans are hand carried to the nondestructive assay module and moved within the module by robot.

Because these cans have passed rigorous drop and crush tests, there are no accidents associated with this module that are expected to generate significant offsite consequences, that is, all of the accidents are a Consequence Severity Category " $D$ " for the public and all are frequency IV, and risk-ranking of 3 or lower (LANL 1997g:19). 


\subsubsection{Preliminary Integrated Process Hazard Analysis}

An integrated PrHA dealing with the potential for an integrated accident associated with the Pit Disassembly and Conversion Demonstration is in preparation. Based on a preliminary analysis by LANL, no additional scenarios have been identified that could potentially impact multiple modules resulting in the release of radioactive materials from more than one module (Ladino 1998).

\subsubsection{Waste Management Impacts}

As discussed in Section 5.3.5, the proposed Pit Disassembly and Conversion Demonstration would generate wastes in the following categories: TRU waste, MLLW, LLW, and hazardous waste. The volume of waste generated by the demonstration would be very small as discussed below. Therefore, the projected increase in the total waste volume for each category would be expected to have little or no impact on current LANL waste management processes and procedures (see Table 6-8). Handling of these wastes would be in accordance with established procedures at LANL, which are compliant with all applicable Federal, and state statutory and regulatory requirements; permits; and DOE orders. Impacts of waste management at LANL are evaluated in the Draft LANL Site-Wide EIS (DOE, 1998a).

\subsubsection{Transuranic Waste}

Crucibles used to contain plutonium during processing and non-fissile pit parts removed during pit disassembly may be sufficiently contaminated to become solid TRU waste. In addition, gloves and glovebox windows and seals would need to be replaced periodically and would be considered TRU waste. Approximately 2 cubic meters of TRU waste would be expected annually from operation of the demonstration. This is appropriately 2.5 percent of the annual TRU waste expected to be generated by all operations at LANL. This TRU waste is packed in drums and the contents recorded at TA-55. The drums are shipped to TA-54, certified, and stored for ultimate disposal at WIPP. The small quantities of TRU waste generated by the proposed action would be expected to have minimal impact on storage capacity at LANL.

\subsubsection{Mixed Low-Level Waste}

Cutting the pit cladding may produce some fines and turnings that would be classified as solid MLLW, depending on the cladding materials. However, the estimated quantity of these materials is less than 150 grams per year and would be considered negligible in comparison to the approximately 7 cubic meters of MLLW generated annually at LANL. MLLW is collected by LANL waste management personnel and stored at TA-54, Areas L and G, pending disposal in accordance with the Site Treatment Plan prepared pursuant to the Federal Facility Compliance Act. Future management of MLLW would also be consistent with any applicable ROD issued pursuant to the WM PEIS.

\subsubsection{Low-Level Waste}

The proposed demonstration would be expected to generate less than 100 liters per year of electrolytic decontamination solutions containing traces of plutonium. These solutions would be transferred to the Radioactive Liquid Waste Treatment Facility at TA-50 for treatment where the waste would be treated by lime/sulfate precipitation. The resulting solid waste would be handled with the other solid LLW generated by the demonstration. Other solid LLW expected to be generated by the demonstration would include protective clothing, metal shavings, gloves, solid beryllium, stainless steel, depleted uranium, and aluminum. It is estimated that approximately 3 cubic meters of solid LLW would be generated annually by the demonstration and buried on the site in pits and shafts designed specifically for this purpose in TA-54, Area $\mathrm{G}$. This is approximately 0.6 percent of the LLW expected to be generated annually by all operations 
Table 6-8. Comparison of Waste Expected to be Generated by the Pit Disassembly and Conversion Demonstration With Current Waste Management Practices at LANL

\begin{tabular}{|c|c|c|c|c|c|c|}
\hline $\begin{array}{c}\text { Waste } \\
\text { Category } \\
\end{array}$ & $\begin{array}{c}\text { Examples of Waste Generated } \\
\text { During Demonstration }\end{array}$ & $\begin{array}{l}\text { Expected Annual } \\
\text { Waste Generated } \\
\text { from Demonstration } \\
\end{array}$ & $\begin{array}{c}\text { Current } \\
\text { Annual Waste } \\
\text { Generated at } \\
\text { LANL } \\
\end{array}$ & $\begin{array}{c}\text { Percent of } \\
\text { Current } \\
\text { Waste } \\
\text { Generation } \\
(\%) \\
\end{array}$ & $\begin{array}{c}\text { Treatment } \\
\text { Capacity } \\
\end{array}$ & Disposal Method \\
\hline TRU & $\begin{array}{l}\text { Gloves; glovebox components, } \\
\text { crucibles, HEPA filters }\end{array}$ & $2 \mathrm{~m}^{3}$ & $81 \mathrm{~m}^{3(a)}$ & 2.5 & $1,080 \mathrm{~m}^{3} / \mathrm{yr}^{(b)}$ & $\begin{array}{l}\text { Treated and stored onsite } \\
\text { awaiting shipment to WIPP }\end{array}$ \\
\hline MLLW & $\begin{array}{l}\text { Solidified solutions, cladding } \\
\text { shavings }\end{array}$ & Negligible ${ }^{(c)}$ & $7 m^{3(a)}$ & NA & $\begin{array}{l}\text { Under development } \\
\text { per Site Treatment } \\
\text { Plan }\end{array}$ & $\begin{array}{l}\text { Shipped offsite for treatment } \\
\text { and disposal }\end{array}$ \\
\hline LLW & $\begin{array}{l}\text { Protective clothing, gloves, } \\
\text { metal, solidified } \\
\text { decontamination solutions }\end{array}$ & $3 m^{3}$ & $521 \mathrm{~m}^{3(u)}$ & 0.6 & $\begin{array}{l}\text { Treatment (and } \\
\text { therefore, } \\
\text { capacity) varies } \\
\text { with waste stream }\end{array}$ & $\begin{array}{l}\text { Buried onsite in pits and } \\
\text { shafts designed and } \\
\text { engineered for this purpose }\end{array}$ \\
\hline Hazardous & $\begin{array}{l}\text { Laboratory solutions, cleaning } \\
\text { solvents, hydraulic fluid }\end{array}$ & $<38 \mathrm{kgs}$ & $90,000 \mathrm{~kg}^{(a)}$ & $<0.1$ & $\begin{array}{l}\text { Treatment (and } \\
\text { therefore, } \\
\text { capacity) varies } \\
\text { with waste stream }\end{array}$ & $\begin{array}{l}\text { Shipped offsite for treatment } \\
\text { and disposal }\end{array}$ \\
\hline
\end{tabular}

'DOE 1996a:3-338, 3-339.

'Less than 150 grams of MLLW is expected to be generated annually during the demonstration. 
at LANL. LLW waste generated by the demonstration would be managed according to the current site practices unless those practices are modified by decisions made pursuant to the WM PEIS.

\subsubsection{Hazardous Waste}

The demonstration would generate a very small amount of liquid hazardous waste including laboratory solutions, cleaning solvents, and hydraulic fluids. It is estimated that approximately 38 kilograms would be generated annually as a result of the demonstration or less than 0.1 percent of the hazardous waste routinely generated by LANL. No disposal facility for hazardous waste exists at LANL. Hazardous wastes are shipped off the site for further treatment and disposal at RCRA permitted commercial facilities in accordance with the ROD for hazardous waste issued pursuant to the WM PEIS (DOE 1998c).

\subsubsection{Transportation Impacts}

The Pit Disassembly and Conversion Demonstration could require transportation of pits from DOE's Pantex Plant or RFETS, and metal from INEEL, SRS, or LLNL. Additionally, HEU removed from disassembled pits would be shipped from LANL to ORR. All shipments would be packaged in Department of Transportation-approved Type-B containers and use safe secure trailers (SSTs).

\subsubsection{Transportation Impacts Analysis Methodology}

Representative overland truck routes have been analyzed for the shipments to LANL and ORR. The routes were selected for analysis consistent with current routing practices and all applicable routing regulations and guidelines. However, the routes were determined for risk assessment purposes. They do not necessarily represent the actual routes that would be used to transport plutonium and HEU in the future. For safety and security reasons, specific routes cannot be publicly identified in advance.

The HIGHWAY (Johnson, et al, 1993) computer code was used for selecting representative highway routes and could be used to help select the actual routes. The HIGHWAY database is a computerized road atlas that currently describes about 386,400 kilometers (240,000 miles) of roads. The Interstate System and all United States-designated highways are included in the database. In addition, most of the principal state highways and many local and community roads are also identified. The code is updated periodically to reflect current road conditions and has been benchmarked against reported mileages and observations of commercial trucking firms. Features in the HIGHWAY code allow the user to select routes that conform to the Department of Transportation regulations. Additionally, the HIGHWAY code contains data on the population densities along the routes. The distances and populations from the HIGHWAY code are part of the information used for the transportation impact analysis.

Since DOE established the Transportation Safeguards Division in 1975, it has accumulated over 110 million kilometers ( 70 million miles) of experience with no accidents or release of radioactive material (DOE 1996a:G-27). However, there are risks associated with such shipments and in order to quantify the potential risks to the public, DOE-developed RADTRAN (Neuhauser and Kanipe 1993). RADTRAN 4 was developed by Sandia National Laboratories to calculate population risk associated with the transportation of radioactive materials by a variety of modes, including truck, rail, air, ship, and barge. This computer code is used for incident-free and accident risk assessments to estimate the impacts on collective populations. RADTRAN 4 population risk calculations take into account both the consequences and probabilities of potential exposure events. The collective population risk is a measure of the total radiological risk posed to society as a whole by the alternatives being considered. As such, the collective population risk is used as the primary means of comparing the various alternatives. 
The transportation accident model assigns accident probabilities to a set of accident categories. Eight accident-severity categories defined in NRC's Final Environmental Statement on the Transportation of Radioactive Material by Air and Other Modes (NRC 1977) were used. The least severe categories (Category I and II) represent low magnitudes of crush force, accident-impact velocity, fire duration, and/or puncture-impact speed. The most severe category (Category VII) represents a large crush force, high accident-impact velocity, long fire duration, and a high puncture-impact speed. The fraction of material released and material aerosolized, and the fraction of that material that is respirable (particles smaller than 10 microns) was assigned based on the accident categories. The analytic approach is consistent with the approach used in the Storage and Disposition Final PEIS.

The nonradiological risk factors are also taken from the Storage and Disposition Final PEIS. Risk factors are provided for fatalities resulting from hydrocarbon emissions (known to contain carcinogens) and transportation accidents (nonradiological fatalities resulting from impact). The risk of transportation accidents involving escort vehicles are included in the estimates. The risk from hydrocarbon emissions for the escort vehicles is much smaller than those from the trucks.

\subsubsection{Transportation Risks Associated with the Proposed Action}

Under the proposed action, plutonium in the form of pits might be shipped to LANL from RFETS or Pantex and in the form of metal from INEEL, SRS, or LINL. HEU recovered from these pits as they are disassembled would be shipped to ORR. As shown in Table 6-9, the greatest risk to the public from these proposed shipments would be from a traffic accident involving the SST or one of its escort vehicles and not from radiological exposure. In terms of the total risk to the public as a result of implementing the proposed action, it is estimated that the proposed action would result in a risk to the public (either as result of a latent cancer or a traffic accident) of less than 0.005 or 5 chances in 1,000 of a fatality.

Based on the results of the transportation risk analysis, it is unlikely that shipping plutonium, in the form of pits or metal, or HEU would result in a fatality. Therefore, no adverse health effects to the public and truck crews would be expected from any scenario involved in the proposed demonstration.

Table 6-9. Overland Transportation Risks for All Materials Under the Proposed Action ${ }^{2}$

\begin{tabular}{|c|c|c|c|c|c|}
\hline \multirow[b]{3}{*}{ Route } & \multicolumn{3}{|c|}{ Routine } & \multicolumn{2}{|c|}{ Accidental } \\
\hline & \multicolumn{2}{|c|}{ Radiological } & \multicolumn{2}{|c|}{ Nonradiological } & \multirow[b]{2}{*}{ Radiological } \\
\hline & Crew $^{b}$ & Public & Emissions & Traffic & \\
\hline $\begin{array}{l}\text { Plutonium shipments from Pantex Plant to } \\
\text { LANL }\end{array}$ & 0.0001 & 0.0007 & 0.0001 & 0.001 & $3 \times 10^{-6}$ \\
\hline Plutonium shipments from RFETS to LANL & $3 \times 10^{-5}$ & 0.0002 & $5 \times 10^{-5}$ & 0.0003 & $1 \times 10^{-6}$ \\
\hline Plutonium shipments from INEEL to LANL" & $7 \times 10^{-6}$ & $5 \times 10^{-5}$ & $5 \times 10^{-6}$ & $7 \times 10^{-5}$ & $3 \times 10^{-7}$ \\
\hline Plutonium shipments from SRS to $\mathrm{LANL}^{c}$ & $1 \times 10^{-5}$ & $7 \times 10^{-5}$ & $1 \times 10^{-5}$ & 0.0001 & $7 \times 10^{-7}$ \\
\hline Plutonium shipments from LLNL to LANLc & $5 \times 10^{-6}$ & $3 \times 10^{-5}$ & $8 \times 10^{-6}$ & $5 \times 10^{-5}$ & $2 \times 10^{-7}$ \\
\hline $\begin{array}{l}\text { Highly enriched uranium shipments from LANL } \\
\text { to ORR }\end{array}$ & $3 \times 10^{-6}$ & $2 \times 10^{-5}$ & $9 \times 10^{-5}$ & 0.0009 & $3 \times 10^{-10}$ \\
\hline
\end{tabular}

${ }^{3}$ All risks are expressed in latent cancer fatalities during the implementation of the proposed action, except for the Accidental-Traffic column, which is a number of nonradiological fatalities.

'The two individuals in the vehicle.

${ }^{c}$ Includes risks associated with a single SST shipment from this site should the need arise. 


\subsubsection{Socioeconomic Impacts}

The proposed demonstration would not affect employment at LANL because no additional personnel are anticipated to be required to support the demonstration. The demonstration would be similar to many other research efforts normally conducted at LANL. It is standard practice for workers at LANL to move from one project to another without any impact on the overall employment level. The demonstration, if undertaken, would be staffed in this manner. Therefore, no significant socioeconomic effects would be expected to result from the proposed action.

\subsubsection{Environmental Justice Impacts}

As discussed above, implementation of the proposed action would pose no significant risk to the general population including minority and low-income populations. Therefore, no disproportionately high and adverse impacts on minority and low-income populations would likely result from implementation of the proposed action.

\subsubsection{Cumulative Impacts}

The Draft LANL Site-Wide EIS, which is incorporated by reference, discusses the cumulative impacts of the proposed demonstration, on-going LANL operations, potential expanded LANL operations, and other activities in the LANL region. As explained in the Draft LANL Site-Wide EIS, expanded operations at LANL including the proposed demonstration and other activities, would result in an additional latent cancer fatality risk of about 0.0002 over the lifetime of the maximally exposed individual.

\subsection{No Action Alternative Impacts}

Under the No Action Alternative, an integrated pit disassembly and conversion line would not be demonstrated at LANL. Research related to these activities would continue to be collected through a series of individual gloveboxes because potential data developed as a result of the demonstration would not be available. There would be no change in the current environmental or health effects associated with work done in PF-4 and TA-55, and these facilities would continue to operate as they do currently.

\subsubsection{Transportation Risks Associated with the No Action Alternative}

Under the No Action Alternative, pits would not be shipped to LANL from RFETS or Pantex, and plutonium metal would not be shipped from INEEL, SRS, or LLNL. Since there would not be any HEU recovered from these pits, there would be no shipments of HEU to ORR. However, DOE has committed to consolidate its inventory of weapons-grade plutonium, so the pits at RFETS would continue to be shipped to Pantex where they would be stored pending a decision on their ultimate disposition in accordance with the ROD that will be issued after the SPD Final EIS is completed. As shown in Table 6-10, the greatest risk to the public from this alternative would continue to be from a traffic accident involving the SST or one of its escort vehicles and not from radiological exposure. In terms of the total risk to the public as a result of implementing the No Action Alternative, it is estimated that this alternative would result in a risk to the public (either as result of a latent cancer or a traffic accident) of less than 0.001 or 1 chance in 1,000 of a fatality.

Based on the results of the transportation risk analysis, it is unlikely that shipping plutonium to Pantex from RFETS under the No Action Alternative would result in a fatality. 
Table 6-10. Overland Transportation Risks for All Materials Under the No Action Alternative ${ }^{\mathrm{a}}$

\begin{tabular}{|c|c|c|c|c|c|}
\hline \multirow[b]{3}{*}{ Route } & \multicolumn{3}{|c|}{ Routine } & \multicolumn{2}{|c|}{ Accidental } \\
\hline & \multicolumn{2}{|c|}{ Radiological } & \multicolumn{2}{|c|}{ Nonradiological } & \multirow[b]{2}{*}{ Radiological } \\
\hline & Crew $^{b}$ & Public & Emissions & Traffic & \\
\hline $\begin{array}{l}\text { Plutonium shipments from } \\
\text { RFETS to Pantex Plant }\end{array}$ & 0.00005 & 0.0003 & 0.00007 & 0.0005 & 0.00008 \\
\hline
\end{tabular}

\subsection{Future Utilization of Pit Disassembly and Conversion Demonstration Equipment}

After completion of the demonstration, the equipment would be placed in a standby mode and later used for training purposes (i.e, operators, supervisors) for the production pit disassembly and conversion facility, should it be built. The modules for which there is no further mission would be decontaminated and decommissioned. The ultimate disposition of the modules has not yet been determined. However, when DOE decides what action to propose regarding the modules, an appropriate NEPA review would be conducted. 


\subsection{RESEARCH AND DEVELOPMENT ACTIVITIES}

In the ROD for the Storage and Disposition Final PEIS, DOE decided to pursue a strategy for plutonium disposition that allows for the implementation of two different approaches for disposition of the United States' surplus plutonium: one would involve the immobilization of some and potentially all surplus weapons plutonium in a glass or ceramic form surrounded by HLW; the other would involve the use of some of the surplus plutonium as MOX fuel in existing commercial light water reactors. The ROD acknowledged that further research, development, and demonstration is needed to provide data for decisions concerning process development, waste characterization, plant design and engineering (for potential disposition-related facilities), and other support activities.

These R\&D activities cover each major area of the surplus plutonium disposition program (pit disassembly and conversion, immobilization, and MOX fuel fabrication) and consist of a number of small-scale projects which in turn consist of a number of individual experiments. As stated before, all of the R\&D activities are ongoing, having been started before 1997, with none of the projects currently being complete. However, some individual experiments have been completed and new ones started. Experiments would be phased over about 3 years and therefore, work on R\&D activities would continue after the issuance of the SPD EIS ROD. Depending on the decisions made in that ROD, individual experiments as well as some of the projects they support may be canceled.

In the interest of furthering the purposes of NEPA and providing full disclosure to the public, a brief description of each R\&D project and the amount and type of nuclear materials involved is being provided in this EA. Some of the project descriptions contain information about individual experiments to provide a better understanding of the work being done and its purpose in the overall surplus plutonium disposition program.

The on-going R\&D projects and experiments described in this section (DOE 1998b; DOE 1997b) have already been reviewed for NEPA compliance by DOE. At five of the sites (Argonne National LaboratoryEast (ANL-E), Oak Ridge National Laboratory (ORNL), Pacific Northwest National Laboratory (PNNL), INEEL, and SRS), these efforts have been categorically excluded from the need for further NEPA review under Category B3. $6^{15}$, because they consist of indoor bench-scale research or demonstration work (Dunigan 1998, Elmore 1998, Grainger 1998, Green 1998, Irving 1998). For the most part, the R\&D activities described in this section are being conducted without the need for construction or modification of existing facilities. In the few activities where construction or modification of facilities was required, all of the changes were within already developed areas. No adverse impacts, including cumulative impacts, are expected during these experiments because of the small quantities of materials being used in these benchscale $R \& D$ projects and because applicable safety and health procedures are in place in these buildings (e.g. HEPA filters, gloveboxes). The R\&D activities at these five sites are using plutonium in amounts well below the administrative limits for the facility in which the work is being performed. At the remaining two sites, LANL and LLNL, the R\&D projects are covered by sitewide EISs which also discuss potential cumulative impacts (DOE 1998a, DOE 1992). The total amount of plutonium used at these two sites would range from 15 to 100 kilograms over the duration of these activities. The amounts used in individual experiments would be well below facility administrative limits. Unless otherwise noted, onsite plutonium is being used for R\&D activities, no offsite shipments are required.

15 As defined in DOE's NEPA Implementing Procedures, Categorical Exclusion B3.6 is applicable to the siting, construction (or modification), operation, and decommissioning of facilities for indoor bench-scale research projects and conventional laboratory operations (e.g., preparation of chemical standards and sample analysis); small-scale research and development projects; and small-scale pilot projects (generally less than two years) conducted to verify a concept before demonstration actions. Construction (or modification) would be within or contiguous to an already developed area (where active utilities and currently used roads are readily accessible) (DOE 1996c:36241). 


\subsection{Immobilization Research and Development}

The Storage and Disposition Final PEIS analyzed the ability of various immobilization technologies to achieve the Spent Fuel Standard for proliferation resistance. The Notice of Intent for the SPD EIS and the SPD Draft EIS stated that the preferred alternative for immobilization is the ceramic can-in-canister technology, using the existing HLW processing operations at the Defense WasteProcessing Facility (DWPF) at SRS. The ROD for the SPD EIS will make the final decision on the immobilization technology to be used for disposition, if it is decided to immobilize some or all of the surplus plutonium.

The proposed can-in-canister demonstration has two stages. The first stage is to immobilize the plutonium in a small can using either a glass or ceramic form. The next step is to place the immobilized cans of plutonium in a rack which is placed in an empty DWPF canister. In the second stage of immobilization, the canister is filled with HLW at DWPF, which adds the radiation barrier necessary to meet the Spent Fuel Standard. The same approach is being evaluated for the Hanford Site in Richland, Washington, which is building a vitrification plant similar to DWPF.

Before DOE can make a decision on the technology to be used to immobilize surplus plutonium, immobilization R\&D is needed to:

- identify a material formulation that satisfies process and long-term performance requirements;

- develop processing equipment, material flow and process controls, operational strategies, and material accountability procedures that minimize impacts on workers and the environment, and the ability to maintain an acceptable implementation schedule;

- demonstrate that individual operations or processing steps fit together seamlessly; and

- demonstrate that the specific immobilized forms meet the Spent Fuel Standard for proliferation resistance (DOE 1996b:3).

On-going work is needed to develop data to: determine which immobilized form, glass or ceramic, performs best $^{16}$; develop material forms compatible with processing (including determining effects of impurities and long-term performance requirements); develop immobilization processes for reliably producing these forms; demonstrate these processes using radioactive materials; and enhance overall proliferation resistance. LLNL is serving as the lead laboratory and host for most of the immobilization $R \& D$, and is being supported by efforts at SRS, ANL-E, and PNNL. Table 7-1 shows the immobilization R\&D projects that are taking place at specific DOE sites, all of the buildings being utilized for the listed R\&D projects at these sites, and the cumulative total plutonium estimated to be used for all the listed projects at each site.

\subsubsection{Development of Data to Support Selection of Preferred Immobilized Form}

To determine the best immobilization form, $R \& D$ is being conducted to judge the glass and ceramic forms against established criteria on a consistent basis. These R\&D activities are being conducted at LLNL to compare can-in-canister and homogeneous approaches, and the final immobilized form, glass or ceramic. Efforts are focusing on resistance to theft and diversion and retrieval or extraction; technical viability; environmental, safety, and health concerns; timeliness; and cost effectiveness.

\footnotetext{
${ }^{16}$ Based on a technical down-selection process, DOE's current research and development efforts are focused on ceramic formulations.
} 


\begin{tabular}{|c|c|c|}
\hline Immobilization R\&D Projects & $\begin{array}{c}\text { Building Number } \\
\text { (Administrative Limit) }^{\mathbf{a}}\end{array}$ & $\begin{array}{l}\text { Quantity of Plutonium Estimated } \\
\text { to be Used in These Projects }\end{array}$ \\
\hline $\begin{array}{l}\text { ANL-E } \\
\text { Glass Formulation Development, Ceramic } \\
\text { Formulation Development, Waste Form } \\
\text { Characterization, Proliferation Resistance } \\
\text { Tests }\end{array}$ & $\begin{array}{l}\text { Building } 205 \\
(400 \mathrm{~g})\end{array}$ & $<300 \mathrm{~g}$ \\
\hline $\begin{array}{l}\text { LLNL } \\
\text { Glass Formulation Development, Glass } \\
\text { Process Development, Ceramic Formulation } \\
\text { Development, Ceramic Process } \\
\text { Development, Waste Form Characterization, } \\
\text { Proliferation Resistance Tests, Can-in- } \\
\text { Canister Technology Demonstrations }\end{array}$ & $\begin{array}{l}\text { Superblock } \\
(700 \mathrm{~kg})^{\mathrm{c}}\end{array}$ & $\begin{array}{l}\text { FY } 97-2 \mathrm{~kg}^{\mathrm{d}} \\
\text { FY } 98-8 \mathrm{~kg}^{\mathrm{d}}\end{array}$ \\
\hline $\begin{array}{l}\text { PNNL } \\
\text { Glass Formulation Development, Glass } \\
\text { Process Development, Waste Form } \\
\text { Characterization, Proliferation Resistance } \\
\text { Tests }\end{array}$ & $\begin{array}{l}\text { Building } 325 \\
(2,759 \mathrm{~g}) \\
\text { Building } 326 \\
(18 \mathrm{~g}) \\
\text { Building } 3720 \\
(18 \mathrm{~g})\end{array}$ & $\begin{array}{l}70 \mathrm{~g} \\
\text { mg quantities } \\
3-5 \mathrm{~g}\end{array}$ \\
\hline $\begin{array}{l}\text { SRS } \\
\text { Glass Formulation Development, Glass } \\
\text { Process Development, Ceramic Formulation } \\
\text { Development, Ceramic Process } \\
\text { Development, Waste Form Characterization, } \\
\text { Proliferation Resistance Tests, Can-in- } \\
\text { Canister Technology Demonstrations }\end{array}$ & $\begin{array}{l}\text { Building 773-A } \\
(2,000 \mathrm{~g})\end{array}$ & $<200 \mathrm{~g}$ \\
\hline $\begin{array}{l}\text { The limit on the amount of plutonium allowed in } \\
\text { shown are the buildings that would be used for th } \\
\text { Amounts listed are cumulative totals for the listed } \\
\text { would be less than the administrative limit. } \\
\text { 'The Superblock is comprised of Buildings } 331,3 \\
\text { 334. The safety analysis report for Building } 334 \\
\text { These amounts are a subset of the quantity of plut } \\
\text { experiments at LLNL (see Table 7-3). } \\
\text { Source: Pearson 1997; Peko 1998a: Vienna 1997. }\end{array}$ & $\begin{array}{l}\text { ilding at any one time is } \\
\text { R\&D projects at a specific } \\
\text { D projects at a specific site. } \\
\text { 334, and } 335 . \text { MD plutoni } \\
\text { her restricts the plutonium } \\
\text { Im being processed throug }\end{array}$ & $\begin{array}{l}\text { on the site-specific safety analysis report; } \\
\text { quantities in the building at any one time } \\
\text { ivities are limited to Buildings } 332 \text { and } \\
\text { o } 12 \mathrm{~kg} \text {. } \\
\text { isassembly and conversion R\&D }\end{array}$ \\
\hline
\end{tabular}

\subsubsection{Formulation Development}

The choice of the first stage immobilization form would affect the design of an immobilization facility, because the immobilization processes differ for each. This choice would also influence the extent of characterization necessary for the product, the waste coming from this facility, potential licensing requirements, and the implementation schedule. For example, the maximum allowable plutonium loading (i,e., the percentage of plutonium that can be encapsulated in the glass or ceramic form) for each immobilized form needs to be determined through $R \& D$ related to process safety and the long-term performance of the immobilized form. Similarly, the loading factor would affect the size and throughput of the processing facility. Formulas for glass or ceramic materials to be used for immobilization and the measurement of various physical and chemical properties of the immobilized material need to be refined to aid the selection 
of the immobilized form, to determine the production processing parameters, and to develop the qualification for placement of the immobilized form into a potential Nuclear Waste Policy Act repository.

LLNL is performing ceramic formulation experiments with support from SRS and ANL-E; while SRS and ANL-E are performing glass formulation experiments; and PNNL is providing testing support. The formulation development project at these laboratories include experiments using the glass concept to determine acceptable impurity concentrations: experiments of the solubility of plutonium, uranium and neutron absorbers as a function of particle size and thermal treatment history of the plutonium feed; experiments in static, manually stirred and control agitation melts; and experiments to establish the devitrification properties as well as key physical properties (e.g., viscosity and thermal conductivity).

\subsubsection{Waste Form Characterization}

The main concern about the performance of the immobilized form in a geologic repository is the potential for separation of the fissionable isotopes of plutonium and uranium from neutron absorbers, inside the waste package, in the environment, or both. The concern is that a separation could result in enough of this material coming together to form a critical mass. DOE experiments are being conducted to characterize waste form degradation and radionuclide release in an environment replicating the presumed repository environment.

\subsubsection{Proliferation Resistance Tests}

The goal of the plutonium disposition program is to place the United States' surplus plutonium into a form from which it can not be easily recovered and used again in nuclear weapons. Proliferation resistance tests are being conducted to ensure that the final glass or ceramic form chosen for immobilization will prevent the return of these materials to a form where they can be used in nuclear weapons. Tests are also being conducted to determine the relative difficulty of recovering plutonium from the glass and ceramic forms. Extraction tests are assessing the degree of difficulty and the cost and time requirements for attempted diversion. These experiments include leaching of the plutonium-bearing forms in sub-boiling solutions (e.g., nitric acid, sulfuric acid) and measurements of the quantity of plutonium released as a function of time.

\subsubsection{Process Development}

Process experiments involve the development and demonstration of prototypical systems for a full-scale plutonium immobilization facility. Development of prototypical glass and ceramic formulation equipment, using kilogram quantities of plutonium, provide needed information, such as shielding requirements and glovebox spacing, for the full-scale design.

The glass process requires the development of a suitable melter system which includes both prototype feeders and product loadout systems contained in a glovebox enclosure for safer operation. Using the tilt-pour melter, DOE is evaluating the characteristics associated with fabricating and pouring multi-kilogram quantities of glass containing plutonium, uranium, and a range of impurities that would be similar to those expected to enter the full-scale facility.

The ceramic process also requires the development of a prototypical feed preparation and cold-pressing system coupled to an appropriate heat cycle to sinter the ceramic pellets. Ceramic samples are prepared to determine the extent to which the precursor or binder materials and the plutonium dioxide feedstock react to produce stable ceramic forms. The ability of the ceramic formulation to incorporate the expected range of impurities in the plutonium feedstocks is being evaluated and preliminary impurity concentration limits established. 


\subsubsection{Can-in-Canister Technology Demonstrations}

Small-scale demonstrations of the various can-in-canister technologies are facilitating the design of a potential full-scale immobilization facility. Fabrication of glass and ceramic forms is being demonstrated in a tilt-pour melter that can produce materials that are prototypical of a full-scale melter and experimental plutonium ceramic process line at LLNL. Several cans of plutonium forms may be produced to validate formulation and plant processes.

\subsection{Reactor-Based and Nuclear Fuels Research and Development}

The second disposition approach being pursued by DOE is the use of weapons-usable plutonium in the fabrication of MOX nuclear fuel for use in commercial light water reactors. R\&D is needed to resolve technical issues associated with applying the large experience base (existing mainly in Europe) of making MOX fuel with recycled reactor-grade plutonium to the fabrication of MOX fuel using weapons-usable plutonium and to develop the data needed for the MOX alternative for the disposition of surplus weaponsusable plutonium.

The compatibility of commercial reactor-grade MOX fuel with commercial light water reactor technologies is well established. However, several differences exist between reactor-grade and weapons-usable plutonium that create technical issues that must be resolved. These differences include: variation in powder characteristics because the weapons material is expected to be converted primarily using a dry pyrochemical process as opposed to the chemical dissolution and precipitation process currently used in Europe; the presence of gallium or other potential impurities in the weapons material; and the variation in plutonium isotopics between reactor-grade and weapons-usable material. $R \& D$ activities fall into two main categories: MOX fuel fabrication and gallium removal. Table 7-2 shows the reactor-based and nuclear fuels R\&D projects that are taking place at specific DOE sites, all of the buildings being utilized for the listed R\&D projects at these sites, and the cumulative total plutonium estimated to be used for all the listed projects at each site.

The potential disposition of plutonium as MOX fuel would involve a mixture of weapons-usable plutonium dioxide and uranium oxide. Any variation in the fabrication process, including the feed materials, will lead to variations in the final fuel product. It is important to quantify the effect these variations would have on the quality of the MOX fuel. Definition and development of the processes, equipment, and specifications for producing plutonium dioxide and uranium oxide feed is essential for qualifying a fuel fabrication process since the proposed MOX fuel fabrication facility may be licensed by the NRC. On-going research is required to determine the range of fabrication parameters that would lead to an acceptable fuel product, that is, one compatible with use in a commercial reactor.

\subsubsection{Light Water Reactor In-Pile Testing}

ORNL is directing in-pile testing experiments to examine the effects of gallium on prototypic but generic, light water reactor MOX fuel. The in-pile testing complements out-of-pile experiments by providing generic irradiation data to supplement the out-of-pile results. Fuel for these experiments, a small number of fuel pellets, are being fabricated at LANL and shipped to INEEL, where the fuel is irradiated in the Advanced Test Reactor (ATR). One or two shipments of fuel pins are being shipped to INEEL in DOT-approved commercial trucks. No significant impacts are expected to result from the transportation of the fuel or its irradiation at ATR. 